\title{
NOTES
}

\section{CONSTRUCTING HOMES FOR THE HOMELESS? SEARCHING FOR A FOURTH AMENDMENT STANDARD}

\author{
DAVID H. STEINBERG
}

\section{INTRODUCTION}

On July 30, 1987, David Mooney, a homeless man, allegedly robbed and murdered a man im Branford, Connecticut, to pay a drug debt to an accomplice. ${ }^{1}$ A week after the victinn's nude body was discovered, the police arrested the accomplice, ${ }^{2}$ an adnitted drug dealer, as he was driving the victim's car. Based on information received from this accomplice, the police issued an arrest warrant for Mooney, who was arrested on the might of August 5, 1987. Later that might, Mooney's girlfriend took a police officer to a bridge underpass where Mooney had been living at the time of the murder. At the underpass, the officer found several items, mcluding a duffel bag, a closed cardboard box, and a suitcase. The officer opened the duffel bag and found a large quantity of quarters, but did not open the other items at that time. After an evidence officer came to the scene, the two officers photographed and tagged the items and took them to the police station where they were opened and inventoried. ${ }^{3}$

At trial, Mooney made two arguments for the suppression of the evidence obtained through the warrantless search of his belongings: First, the police violated Mooney's rights under the Fourth Amendment to the Umited States Constitution, ${ }^{4}$ when they mvaded his "home" under

1. State v. Mooney, 588 A.2d 145, 149 (Conn.), cert. denied, 112 S. Ct. 330 (1991). Witnesses testified at trial that Mooney "hustled" gay men to obtain money and drugs. Brief for Respondent at 3, Mooney (No. 13,737). After Mooney and the victim took a shower together, Mooney began beating the victim. Then, while Mooney strangled the victim with an electric clock cord, the accomplice robbed the condomimium, taking a VCR, a quantity of coins, and some other items. Id. at 2-4.

2. The accomplice was tried separately and convicted of felony murder, first-degree robbery, and first-degrec burglary. Brief for Respondent at 2 n.2, Mooney (No. 13,737).

3. Mooney, 588 A.2d at 150-51.

4. The Fourth Amendment provides:

The right of the people to be secure in their persons, houses, papers, and effects, against unreasonable searches and seizures, shall not be violated, and no Warrants shall issue, but 
the bridge abutment without a warrant; 5 and second, the police violated his Fourth Amendment rights when they searched his closed containers found under the abutnient. ${ }^{6}$ The court denied Mooney's motion to suppress the evidence, and he was convicted upon a jury trial of felony niurder and robbery in the first degree. ${ }^{7}$ Mooney appealed to the Suprenie Court of Connecticut, which reversed the judgment, ${ }^{8}$ holding that the closed container search violated Mooney's Fourth Amendnient protection agamst unlawful search and seizure. ${ }^{9}$ The court never decided the first issue regarding the defendant's "hone" because it found nerit in his second claim. However, the court assumed as true the state's contention that the defendant conld not manifest a reasonable expectation of privacy in his "home."10 Mooney raised the legal questions of whether homeless people can assert legitimate Fourtl Amendment riglits to their "homes" and whether they can reasonably expect privacy in the contents of their belongings left unattended.

Any atteinpt to define what protection is available under the Fourth Amendment inust start with the landmark case of Katz v. United States. ${ }^{11}$ In Katz, the United States Supreme Court reformnlated its test for determining whether a warrantless police search violates the Fourth Amendment's protection against unreasonable search and seizure. The Court turned away from the traditional approach to illegal search and seizure and formed a "privacy" analysis. ${ }^{12}$ Traditionally, the Court had examined the area searched to determine whether it was "constitutionally protected." 13 In Katz, the Court adopted a two-part "privacy" test, determining whether the defendant had a subjective expectation of privacy $m$ the searched subject nuatter, and whether this expectation is one

upon probable cause, supported by Oath or affirmation, and particularly describing the place to be searched, and the persons or things to be seized.

U.S. CoNST. amend. IV. Although Mooney also claimed that the search violated article I, section 7 of the Connecticut Constitution's prohibition against illegal searches and seizures, he presented no separate analysis to that end. See Mooney, 588 A.2d at 150 n.5. The court declined to consider his claim under the Connecticut Constitution and did not resolve whether grcater protection could be found there. Id.

5. Mooney, $588 \mathrm{~A} .2 \mathrm{~d}$ at 150 .

6. Id.

7. Id. at 149. Mooney was sentenced to sixty years imprisonment, to be suspended after fifty years. Brief for Respondent at 1, Mooney (No. 13,737).

8. Mooney, 588 A.2d at 149.

9. Id. at 154 .

10. Id. at 152 .

11. 389 U.S. 347 (1967). Katz involved a wiretap on a public telephone booth that the defendant used to communicate wagers in violation of a federal statute. Id. at 348.

12. Id. at 361 (Harlan, J., concurring). The approach set forth in Justice Harlan's concurring opinion was adopted by the Court in Terry v. Ohio, 392 U.S. 1, 9 (1968).

13. See infra Part I(A). 
society is willing to accept as reasonable. ${ }^{14}$ This test later came to be known as the "reasonable expectation of privacy" test. ${ }^{15}$

The Katz test allowed the Court to overcome the often undesirable logical consequences of the "constitutionally protected area" standard, but practical application of the test proved difficult without an examination of the defendants' underlying property interests. ${ }^{16}$ Although Katz sought to escape the property-based criteria of the "constitutionally protected area" formulation, these factors are essential in determining the reasonable expectation of a criminal defendant. For example, the Court held in California v. Greenwood ${ }^{17}$ that a warrantless search of closed trash bags left at the curb did not violate the defendant's rights because he had abandoned the bags for Fourth Amendment purposes ${ }^{18}$ and therefore could not have had a reasonable expectation of privacy in their contents. Other courts have used the Katz framework to allow warrantless searches of closed belongings left temporarily unattended. ${ }^{19}$

Mooney is one of the latest cases illustrating a jurisprudential difficulty im applyimg the Supreme Court's current search and seizure doctrime. The Supreme Court of Connecticut's conclusion, that Mooney, a

14. 389 U.S. at 361 (Harlan, J., concurring).

15. See Terry, 392 U.S. at 9 . The test set out in Katz could be read to inply that society must weigh the subjective expectation of the defendant and determine its reasonableness given the defendant's circumstances. The Court does not apply Katz in this way. Instead, the "reasonable expectation of privacy" test is an objective one that ascertains whether the search infringes on the societal values protected by the Amendment. See infra text accompanying notes 62-66.

16. For the purposes of this Note, I will consider only two types of property interests-proprietary (i.e., ownership-derived rights) and possessory (i.e., rights derived from the power to exclude others from items or areas legally possessed, though not necessarily accompanied by title). See BLACK'S LAw Dictionary 1165, 1219 (6th ed. 1990). Proprietary interests will often prove insuffcient to create a legitimate Fourth Amendment right. See infra note 82. Interestingly, although proprietary rights supersede possessory rights in a property dispute, possessory interests are more powerful in a Fourth Amendment context because the right to exclude others is more closely associated with the principles that the Amendment protects. Nevertheless, even a possessory interest may not be enough to create a legitimate Fourth Amendment interest. See infra notes 83-85 and accompanying text.

17. 486 U.S. 35 (1988).

18. Although the traditional definition of abandonment requires an intent to relinquish ownership, see BLACK's LAW DICTIONARY, supra note 16, at 2, courts have held that the test for intent in a Fourth Amendment context is an objective one, determined by the actions of the defendant. See, e.g., United States v. Thomas, 864 F.2d 843, 845 (D.C. Cir. 1989). Conduct is considered abandonment in the context of search and seizure when it exposes an ordinarily private possession to the scrutiny of the public-even if the defendant does not intend to relinquish ownership. See id.; infra Part III(C).

19. E.g., Thomas, 864 F.2d at 846-47 (expectation of privacy in gym bag left behind in a public hallway held not to have been reasonable even though defendant intended to return to retrieve bag); see also United States v. Ruckman, 806 F.2d 1471 (10th Cir. 1986) (defendant had no reasonable expectation of privacy in cave located on public land); infra text accompanying notes 152-55. 
homeless defendant, had a reasonable expectation of privacy in the contents of his closed containers left under a bridge underpass, violates the Umited States Supreme Court's ruling in Greenwood that closed but abandoned containers are not protected by the Fourth Amendment. Furthermore, the court ignored the Supreme Court's holdings in Oliver v. United States ${ }^{20}$ and California v. Ciraolo ${ }^{21}$ that open areas are not conducive to Fourth Amendment protection. Yet despite conflicting authorities on how to deal with these types of searches, and the magnitude of the homelessness problem in America, ${ }^{22}$ the Supreme Court demied review. ${ }^{23}$ The purpose of this Note is to analyze the "reasonable expectation" standard and assess the implications of this standard with regard to homeless persons.

Part I of this Note traces the historical underpinnings of the current "reasonable expectation" standard, from the traditional "constitutionally protected area" approach to the Katz reformulation of search and seizure into a privacy concept. Part II argues that the Supreme Court has consistently used property imterests as a gauge for whether a person has a legitimate interest that the Fourth Amendment will protect. Part II, furthermore, concludes that such property inquiries are appropriate and necessary. Part III discusses the various post-Katz cases which examine property interests in order to assess Fourth Amendment interests. In particular, Part III analyzes various types of cases that shed hight on the homeless person's Fourth Amendment interest, including cases that involve searches of open fields, ${ }^{24}$ closed contamer searches, ${ }^{25}$ searches of abandoned items, ${ }^{26}$ and searches of trespassers' belongings. ${ }^{27}$ Part IV

20. 466 U.S. 170 (1984).

21. 476 U.S. 207 (1986).

22. Statistics reveal that homelessness has dramatically increased during the last decade. See Connecticnt Coalition for the Homeless, Who Is Homeless in Connecticut?, reprinted in Brief of the Defendant-Appellant at Appendix 19A, State v. Mooney, 588 A.2d 145 (Conn. 1991) (No. 13,737) (reporting that homelessness in Connecticut increased 14\% from 1988 to 1989 based on shelter usage); United States Conference of Mayors, $A$ Status Report on Homelessness in America's Cities: 1989, reprinted in Brief of the Defendant-Appellant at Appendix 25A, 27A, Mooney (No. 13,737) (reporting that requests for emergency shelter increased an average of $25 \%$ in 27 survey cities). But see Jay Mathews, Rethinking Homeless Myths, NEwsweEk, Apr. 6, 1992, at 29 ("[T] $]$ he nation is almost over the homeless hump.").

23. Connecticut v. Mooney, $112 \mathrm{~S}$. Ct. 330 (1991). Instead of a retrial, Mooney pleaded no contest to first-degree manslaughter and received a fifteen-year sentence, to be suspended after seven years. Homeless Man Could Be Released, HARTFORD CourANT, Jan. 8, 1992, at B11. Because he has already spent five years in jail dnring his appeal, he will be eligible for parole in late 1992. Id.

24. See infra Part III(A).

25. See infra Part III(B).

26. See infra Part III(C).

27. See infra Part III(D). 
analyzes the Mooney decision. The Supreme Court of Connecticut ignored the post-Katz case law and misapplied the "reasonable expectation" standard. Part V concludes that the search conducted in Mooney was not violative of the defendant's Fourth Amendment rights because the defendant could not have manifested a reasonable expectation of privacy in his belongings left under the public bridge abutment. Katz's progeny determined that the correct inquiry for Fourth Amendment jurisprudence-whether a defendant has a reasonable expectation of privacy -is properly determined by assessing property interests. The harsh but necessary consequence of this test is that lomeless people will often be precluded from asserting Fourth Amendinent protection.

\section{A BLUEPRint For the Fourth AMENDMENT: KATZ V. UNITED STATES}

Searcli and seizure law in this country has developed greatly over the last two centuries. ${ }^{28}$ Much of the recent development of search and seizure has focused on what constitutes a search. ${ }^{29}$ As one commentator has suggested, "[1]aw enforcement practices are not required by the [F]ourth [A]mendment to be reasonable unless they are either 'searches' or 'seizures." "30 Thus, ouly when the police actions have announted to an actual Fourth Amendment search of a defendant's home or belongings has the Court addressed the reasonableness of the intrusion. This determination was once based on whether the area searched was protected; after $K a t z$, it was based on the privacy expectation of the defendant.

28. For a general discussion of the history of search and seizure in England and the United States, see 1 Wayne R. LaFave, Search and Seizure (2d ed. 1987); Jacob W. LaNdyNSki, SEarch and Seizure and the Supreme Court (1966); Nelson B. Lasson, The History and Development of the Fourth Amendment to the United States Constitution (1937). The primary focus of this development, however, has not been the issue of the "reasonableness" of a warrantless search, but rather the creation and refinement of the exclusionary rule, which requires that evidence obtained from unlawful searches be excluded from trial. See Mapp v. Ohio, 367 U.S. 643 (1961). For a discussion of the exclusionary rule, see generally Potter Stewart, The Road to Mapp v. Ohio and Beyond: The Origins, Development and Future of the Exclusionary Rule in Search-and-Seizure Cases, 83 CoLuM. L. REv. 1365 (1983).

29. It should be noted at the outset, however, that the Supreme Court has never sought to define strictly what constitutes a "search" within the meaning of the Fourth Amendment. 1 LAFAVE, supra note $28, \S 2.1$ (a). The Court has always been hesitant to create rigid guidelines for Fourth Amendment analyses because search and seizure law must be able to accommodate casespecific circumstances.

30. Anthony G. Amsterdam, Perspectives on the Fourth Amendment, 58 MinN. L. REv. 349, 356 (1974). 


\section{A. The Pre-Katz Approach to Warrantless Searches}

In the 1920s, police actions did not constitute a search unless there was a physical invasion of a constitutionally protected area. For example, in Olmstead v. United States, ${ }^{31}$ the Court determined that a wiretap placed on defendant's telephone line did not amount to a search because no physical intrusion into a constitutionally protected area was shown. Chief Justice Taft, writing for the majority, concluded that there was no search or seizure because there was no entry into the defendant's house or office. ${ }^{32}$ Thus the majority delineated a construction of the Fourth Amendment requiring a physical invasion of a protected area.

Justice Brandeis argued in his dissent, however, that the Constitution must keep in step with the times: "When the Fourth and Fifth Amendments were adopted, 'the form that evil had theretofore taken' had been necessarily simple." 33 Because "[s]ubtler and more far-reaching" ${ }^{34}$ inethods of obtaining evidence are available with modern teclinol-

ogy, Justice Brandeis continued, the Fourth Amendment must be construed as a general right to privacy: "[T]he right to be let alone . . . [is] the right most valued by civilized inen. To protect, that right, every unjustifiable intrusion by the government upon the privacy of the individual, whatever the means employed, inust be deemed a violation of the Fourth Amendment."35 Justice Brandeis concluded that the location of the wiretap was immaterial. ${ }^{36}$ In his view, the physical invasion need not violate a protected area to invoke Fourth Amendinent protection as long as the physical invasion violated a privacy right. But even this view,

31. 277 U.S. 438 (1928).

32. Id. at 464. Chief Justice Taft's belief in a "physical penetration" requirement of the Fourth Amendment forced him to almost absurd results: "The reasonable view is that one who installs in his house a telephone instrument with connecting wires intends to project his voice to those quite outside, and that the wires beyond his house, and messages while passing over them, are not within the protection of the Fourth Amendment." Id. at 466 (emphasis added). It is unlikely that the use of new technology to transmit private conversations is intended to be broadcasted as if shouted out a window. Compare Chief Justice Taft's view of the role of increased technology in Fourth Amendment analysis to that of the dissenting Justice Brandeis: "Ways may some day be developed by which the government, without reinoving papers from secret drawers, can reproduce them in court .... Can it be that the Constitution affords no protection against such invasions of individual security?" Id. at 474 (Brandeis, J., dissenting) (footnotes ornitted).

33. Id. at 473 (citation omitted).

34. Id.

35. Id. at 478-79. Compare this view to that in Katz: "[T] he Fourth Amendment cannot be translated into a general constitutional 'right to privacy.' "' Katz v. United States, 389 U.S. 347, 350 (1967).

36. Olmstead, 277 U.S. at 479 (Brandeis, J., dissenting). 
advocating a privacy approach to Fourth Amendinent analysis, utilized the physical intrusion inodel. ${ }^{37}$

The issue of non-physical searches posed serious difficulties for the Fourth Amendment status quo. This inability to move beyond the physical intrusion test forced the Olmstead Court to liken the use of a telephone to shouting out a window. ${ }^{38}$ Yet it seems clear that use of a telephone cannot be equated with a general waiver of privacy. Equally ridiculous were the positions espoused by the Olmstead dissenters who were forced either to interpret the Fourth Amendment as granting a general right to privacy ${ }^{39}$ or to provide a physical explanation of non-physical invasions. ${ }^{40}$ All three positions proved to be undesirable.

Electroinc surveillance cases contimued to trouble the Court. In Olmstead, the Court established the "physical invasion" standard; yet as technology advanced, it became easier to eavesdrop without physical intrusion. In Goldman v. United States, ${ }^{41}$ the police placed a "detectaphone" 42 on the other side of a party wall to listen to conversations conducted in the adjoining office. The Court determined that the police's conduct did not constitute a violation of the Fourth Amendment because "the eavesdropping had not been accomplished by means of an unauthorized physical encroachment withm a constitutionally protected area." 43 Because the electromic device was placed on the other side of the party wall (and therefore not in the defendant's protected area), the conduct did not constitute a search.

In Silverman v. United States, ${ }^{44}$ the police placed a "spike mike"45 in the heating ducts of the defendant's house. Because there was an actual mtrusion into a constitutionally protected area, the Court concluded that the conduct constituted a search violative of the Fourth Amendment. 46 The concurring Justice Douglas, although agreeing that the search was illegal, began to question the wisdom of the physical intrusion standard:

37. Justice Butler went even further in using the physical intrusion model: "[T]he exclusive use of the wire belongs to the persons served by it." Id. at 487 (Butler, J., dissenting) (enphasis added).

38. See supra note 32.

39. See supra text accompanying note 35 .

40. See supra note 37.

41. 316 U.S. 129 (1942),

42. A detectaphone is an electronic listening device that amplifies sound from a particular direction. See id. at 131.

43. Id. at 134-35; see also On Lee v. United States, 343 U.S. 747 (1952) (holding that secretly rccorded conversations with a federal officer were not protected by the Fourth Amendment because no physical invasion occurred).

44. 365 U.S. 505 (1961).

45. A spike mike amplifies all sound within a given radius. See id. at 506.

46. Id. at 512 . 
An electronic device on the outside wall of a house is a permissible invasion of privacy ... while an electronic device that penetrates the wall . . . is not. . . . Our concern should not be with the trivialities of the local law of trespass .... . [O]ur sole concern should be with whether the privacy of the honie was invaded. ${ }^{47}$

Even this approach, however, utilized the physical invasion inodel by dealing with the privacy of the area searched, not the expectations of the defendant. 48

The electronic surveillance cases forced the Court to question seriously its underlying Fourth Amendnient philosophy. As the protection against unlawful search and seizure had developed froni the common law trespass doctrine, the physical intrusion nodel served the Court well when the typical search involved an invasion of the honie or office. Electronic surveillance presented difficulties never conteinplated by the drafters of the Fourth Amendment. ${ }^{49}$ With Katz, the Court adopted a new approach to analyzing searches-focusing on the reasonable expectation of the defendant instead of on the physical penetration of a constitutionally protected area. Although this approach is sensible, the Court still inust look to property interests to determine whether the expectation of privacy is reasonable.

\section{B. The Katz Reformulation: The Abandonment of the Property-Based Analysis}

The Court's difficulty in dealing with electronic surveillance cases was due to the inadequacy of the "physical invasion" standard. In Katz v. United States, ${ }^{50}$ the Court finally abandoned this standard, replacing it with a privacy approach similar to the one Justice Brandeis had advocated forty years earher in his Olmstead dissent. In Katz, the defendant was convicted of transmitting wagers by wire across state lines. FBI agents intercepted the transmission by placing a wiretap on the public phone booth where Katz was communicating these wagers. ${ }^{51}$ The issue before the Court went to the heart of the Fourth Amendinent debate: Is a public telephone booth a constitutionally protected area, and if so,

47. Id. at 512-13 (Douglas, J., concurring).

48. See 1 LAFAVE, supra note 28, § 2.1(a). LaFave discusses the pre-Katz Supreme Court cases in which various areas mentioned by the Fourth Amendment were held to be protected: " 'persons,' including the bodies and clothing of individuals; 'houses,' including apartments, hotel rooms, garages, business offices, stores, and warehouses; 'papers,' such as letters; and 'effects,' such as automobiles." Id. (citations omitted); $c f$. Lanza v. New York, 370 U.S. 139 (1962) (holding that a jail cell is not a constitutionally protected area).

49. But cf. Katz, 389 U.S. at 366 (Black, J., dissenting) (noting that the Framers were aware of the practice of eavesdropping).

50. 389 U.S. 347 (1967).

51. Id. at 348. 
must the electronic surveillance physically penetrate the area to invoke Fourth Amendment protection?

Justice Stewart, writing for the majority, ${ }^{52}$ rejected this formulation of the issue: "[T]he correct solution of Fourth Amendment problems is not necessarily promoted by incantation of the phrase 'constitutionally protected area." "53 According to Justice Stewart, search and seizure analysis should not focus on the area that is searched, but rather on the reasonable expectation of the defendant. ${ }^{54}$ It is reasonable to assunie that a defendant who enters a phone booth does not expect to broadcast his conversation to the world. 55 Thus, any interception of such conversation, made without a warrant, 56 is a violation of the Fourth Amendment as long as the defendant manifested a reasonable expectation of privacy. The Court also rejected the requirement of a physical invasion, explicitly overruling Goldman. ${ }^{57}$ Justice Harlan, in his concurring opinion, explained the new test: "[T]here is a twofold requirement, first that a person have exhibited an actual (subjective) expectation of privacy and, second, that the expectation be one that society is prepared to recognize as 'reasonable." "58

\section{Interpreting Katz}

The command of Katz seeined clear: No warrantless search was lawful if the accused manifested a reasonable expectation of privacy in the item searched. However, the application of the reasonable expectation standard was anything but clear. Indeed, commentators have been struggling with the Katz test for years. This Section explains four important aspects of this test that must be considered when applying Katz. First, although the Katz test requires that two criteria be met, the focus of the Katz test is on the reasonable expectation component and not on

52. In a case before eight Justices, five opinions were written. Justice Stewart wrote for the majority; Justice Douglas wrote a separate concurring opinion (joined by Justice Brennan); Justice Harlan wrote a separate concurring opinion; Justice White wrote a separate concurring opinion; and Justice Black dissented. Justice Marshall took no part in the consideration of the case.

53. Katz, 389 U.S. at 350.

54. "[T]he Fourth Amendment protects people, not places." Id. at 351.

55. Id. at 352.

56. See Berger v. New York, 388 U.S. 41, 63-64 (1967) (stating that the judiciary may, under certain circumstances, issue warrants to place wiretaps on phone lines).

57. "[T]he absence of [a] penetration was at one time thought to foreclose further Fourth Amendment inquiry ... [but] the reach of that Amendment cannot turn upon the presence or absence of a physical intrusion . . . Katz, 389 U.S. at 352-53. But see id. at 366 (Black, J., dissenting): "[T]he Framers were aware of this practice [eavesdropping], and if they had desired to outlaw or restrict the use of evidence obtained by eavesdropping, . . . they would have used the appropriate language to do so in the Fourth Amendment."

58. Id. at 361 (Harlan, J., concurring). 
the subjective expectation component. ${ }^{59}$ As one commentator points out, "[a]n actual, subjective expectation of privacy obviously has no place in a statement of what Katz held ... . If it [did], the governinent could diminish each person's subjective expectation of privacy merely by announcing ... [that] we were all forthwith being placed under comprehensive electronic surveillance." 60 This message would effectively put us all on notice that our homes and belongings could be searched at any time. Anyone who heard (and beheved) this message could not actually expect privacy. To avoid this absurd result, the only real question should be whether the defendant manifested an expectation of privacy that is reasonable in society's eyes. ${ }^{61}$

59. See Eric D. Bender, Note, The Fourth Amendment in the Age of Aerial Surveillance: Curtains for the Curtilage?, 60 N.Y.U. L. REv. 725, 753 (1985). Another way of viewing the first component is that the defendant must exhibit a subjective expectation of privacy, not merely have such an expectation. Id. at 743.

60. Amsterdam, supra note 30, at 384.

61. Justice Harlan ultimately recognized that the subjective expectation was not as important as the objective reasonableness. See United States v. White, 401 U.S. 745, 786 (1971) (Harlan, J., dissenting) ("The analysis must ... transcend the search for subjective expectations."). As LaFave notes, "the point is sometimes missed by lower courts." 1 LAFAVE, supra note 28, $\$ 2.1$ (c) n.66 (citing Gillet v. State, 588 S.W.2d 361 (Tex. Crim. App. 1979) (holding that defendant's lack of subjective expectation of privacy could defeat his Fourth Amendment rights)).

Applying Ockham's razor we can eliminate the requirement of a subjective expectation altogether. A defendant possessing neither a subjective nor an objective expectation of privacy obviously would not be protected by the Fourth Amendment. A defendant possessing both a subjective and an objective expectation of privacy obviously would be protected. However, a defendant possessing only a subjective expectation (he honestly believes his belongings will remain private) but not an objective expectation (he honestly beheves his belongings will remaim private while left unattended at a kleptomaniacs convention) would not receive the protection of the Fourth Amendment if a police officer should discover and open the belongings. Such a defendant fails the objective test because his behavior (leaving the belongings unattended where they are likely to be inspected) does not exhibit an expectation of privacy that is objectively reasonable. What about a defendant who believes that his belongings will not remain private, but otherwise exhibits behavior suggesting an objectively reasonable expectation of privacy? For example, if a man actually believes that the police will break into his home without a warrant and search his belongings, but he takes every precaution to ensure that they renam private (in this case, leaving them at home would be enough), will his lack of a subjective expectation of privacy prevent the Fourth Amendment from protecting him? Clearly not. Thus, the subjective component to Katz's two-part test can and should be ignored. Katz only requires an objective (i.e., reasonable) expectation of privacy determined by societal standards.

Because the objective determination is based on society's perception of what constitutes a reasonable expectation, the test is not "objective" in the strictest sense of the word. At best, Katz requires an "inter-subjective" examination of the privacy expectation. An inter-subjective test only requires agreement among members of society, not logical conclusions derived from first principles. For a discussion of the differences between "subjective," "inter-subjective," and "objective" criteria, see AlasDair MACINTYRE, AFTER VIRTUE 6-22, $62-78$ (2d ed. 1984); J.L. Mackie, The Subjectivity of Values, in Essays ON MORAL REALISM 95, 99-102, 105-09 (Geoffrey Sayre-McCord ed., 1988); Geoffrey Sayre-McCord, The Many Moral Realisms, in Essays ON MORAL REALISM, supra, at 1, 14-22. The importance of Katz's inter-subjectivism is that the requirements of reasonableness may change over time as society adopts new standards of morality and justice. 
Second, a defendant must produce more than just a "reasonable expectation" im order to rely on Fourth Amendment protection. In United States v. White, ${ }^{62}$ the Court characterized the Katz test as requiring "justifiable"63 expectations, which are "[those] expectations the Fourth Amendment will protect im the absence of a warrant." 64 Thus, a criminal, having taken steps to ensure that his actions were safe from inspection, may have a reasonable expectation of privacy. But these actions would not necessarily be sufficient to receive Fourth Amendment protection. As one commentator illustrates:

If two narcotics peddlers were to rely on the privacy of a desolate corner of Central Park in the middle of the night to carry out an illegal transaction, this would be a reasonable expectation of privacy; there would be virtually no risk of discovery. Yet if by extraordinary good luck a patrolman were to illuninate the desolate spot with his flashlight, the criminals would be unable to suppress the officer's testiniony as a violation of their rights under the fourth amendment. ${ }^{65}$

Thus, carefully concealed criminal evidence is not protected by the Fourth Amendment although the expectation of privacy may be "reasonable" under the circumstances. Likewise, non-criminal activities may not be protected by the Fourth Amendment if they do not rise to the level of a societally protected interest: The privacy expectation must be one that "society is prepared to recognize as 'reasonable." "66

Third, although the Court rejected the "constitutionally protected area" standard, an analysis of the defendant's expectations will almost certainly require reference to the place searched. ${ }^{67}$ There is no question

62. 401 U.S. 745 (1971).

63. The Court uses the terms "legitimate" and "justifiable" alternately to indicate this additional burden. I will use the term "legitimate."

64. 401 U.S. at 752.

65. Note, From Private Places to Personal Privacy: A Post-Katz Study of Fourth Amendment Protection, 43 N.Y.U. L. REv. 968, 983 (1968).

66. Katz v. United States, 389 U.S. 347, 361 (1967) (Harlan, J., concurring) (emphasis added). Not all reasonable expectations of privacy will generate Fonrth Amendment protection. Although society may agree that a defendant exhibited a reasonable expectation of privacy by carefully concealing his criminal activities, a defendant will not be protected by the Fourth Amendment in those instances where his expectation is illegitimate. This requirement creates an even tougher standard for criminal defendants: To retain the protection of the Fourth Amendment, not only must the conduct exhibit a reasonable expectation of privacy (determined by society's reasonableness standard), but this expectation must be "legitimate" in some further sense. The content of the term "legitimate" has never been fully explained by the Court. See Oliver v. United States, 466 U.S. 170, 197 (1984) (Marshall, J., dissenting) ("The Fourth Amendment . . . embodies and gives effect to our collective sense of the degrec to which men and women, in civilized society, are entitled to be let alone' by their governments.").

67. Justice Harlan argued that any determination of Fourth Amendment protection "requires reference to a 'place.' " Katz, 389 U.S. at 361 (Harlan, J., concurring). Whether Fourth Amendment challenges can be resolved without reference to the area searched is doubtful. Becausc the Katz 
that a person can have a privacy interest outside the traditionally protected area as long as the expectation of privacy in the object is reasonable. ${ }^{68}$ However, any estimation of the reasonableness of the defendant's expectation must inake soine reference to the place. The location of the search is relevant to the extent that it affects the expectations of the defendant. In fact, to determine whether a defendant had a reasonable expectation of privacy, it is necessary to examine the surrounding circuinstances. ${ }^{69}$ Not only will the location of the search be relevant, but so will other property-oriented factors, such as the property rights of the defendant (i.e., proprietary and possessory rights, including the right to exclude), abandoninent of the searched itein, and the defendant's status as a trespasser. ${ }^{70}$

Fourth, the Katz Court did not replace the old standard with a new one. Instead, the Court apphed an essentially "standardless" test.71 Katz sought to escape a "talismanic solution to every Fourth Amendment problem"72 by using a flexible "reasonable expectation" test. The test was not to be applied mechanically; rather, the test was meant to apply to any situation or location, as long as the expectation of privacy is reasonable in society's eyes. The rationale for Katz's standardless approach is sound. The Fourth Amendment protects people against intrusion. This right is fundamental and is determined by what society values. In the early years of the Fourth Amendinent, the protection extended only to one's house and office; but as society's understanding of personal liberty grew, the protection of the Fourth Amendment did as well. The

test depends on the general circumstances of the search and on society's perception of the defendant's expectation of privacy, the place of the search is often highly relevant. So even though "the Fourth Amendment protects people, not places," id. at 351, the place searched cannot be ignored. In Rakas y. Illinois, Justice Rehnquist noted:

Legitimation of expectations of privacy ... must have a source outside of the Fourth Amendment, either by reference to concepts of real or personal property law or to understandings that are recognized and permitted by society.... [O]ne who owns or lawfully possesses or controls property will in all likelihood have a legitimate expectation of privacy by virtue of [the] right to exclude [others]. Expectations of privacy protected by the Fourth Amendment, of course, need not be based on a common-law interest in real or personal property, or on the invasion of such an interest. . . . But by focusing on legitimatc expectations of privacy in Fourth Amendmeut jurisprudence, the Court has not altogether abandoned use of property concepts in determining the presence or absence of the privacy interests protected by that Amendment.

439 U.S. 128, 144 n.12 (1978); see also Oliver, 466 U.S. at 188-91 (Marshall, J., dissenting); infra text accoinpanying note 106-10.

68. "What a person knowingly exposes to the public, even in his own home or office, is not a subject of Fourth Amendinent protection. . . . But what he seeks to preserve as private, even in an area accessible to the public, inay be constitutionally protected." Katz, 389 U.S. at 351 (citations omitted).

69. See Rakas, 439 U.S. at 152 (Powell, J., concurring).

70. See infra Part III.

71. See Note, Protecting Privacy under the Fourth Amendment, 91 YALE L.J. 313, 328 (1981).

72. 389 U.S. at 351 n.9. 
Fourth Amendment protects people anywhere they are as long as that privacy interest they possessed at home is still with them. This is one way of thinking about Katz: The metaphysical legitimacy of the privacy interest at home extends to certain "reasonable" and "legitimate" circuinstances outside the home. Katz is faithful to the Fourth Amendment's goal of protecting the values that society regards as important. Any other approach, whether the former "constitutionally protected area" rule of Olmstead, Goldman, and Silverman, or the overbroad general right to privacy suggested by Justice Brandeis in Olmstead, misses the point of what the Fourth Amendment protects.

The Katz test is difficult to apply because it is not a rule, but an extension of society's abhorrence of privacy invasion. But because the test rehes on society's perception of the defendant's reasonable expectation, the law can change with time: What is a reasonable expectation of privacy today may not, as we shall see, be a reasonable expectation of privacy tomorrow.

\section{Laying the Foundation: Property as a Basis for Privacy}

Katz sought to escape the "property-based" theory of Fourth Amendment analysis, which had focused on the area searched. However, the standardless framework that Katz set forth forced courts to "fill in" the details. Katz's focus on the defendant's expectation was logical; but by requiring that the defendant's expectation of privacy be "reasonable in society's eyes," some criteria had to be used to determme what was "reasonable." Because one of the most important rights associated with ownership of property is the right to exclude others, ${ }^{73}$ it made sense to look to property rights in assessing the individual's right to refuse a search: Does the individual have the requisite property interest to exclude the pohice? The four categories involved in Mooney-open fields, closed containers, abandonment, and trespass-all shed light on an individual's property rights. Of course, the interest necessary to exclude the police from searching one's effects without a warrant is not exactly the same as a property interest. ${ }^{74}$ Nevertheless, property interests will be crucial in any reasonable expectation of a defendant asserting Fourth Amendinent protection.

\section{A. Property Rights as a Basis for Society}

"As long as a system of property rights protects and gives meaning to people's right to be left in peace, individual initiative will produce the

73. See infra note 107 .

74. See infra note 82 . 
essential elements of human flourishing."75 This proposition-that the enforcement of property rights will ensure a just society-has been debated for more than two thousand years. ${ }^{76}$ It is not within the scope of this Note to further that debate. Nevertheless, it is essential to understand that property rights are the only available measure of a person's privacy. Every claim to government protection of a privacy interest will ultimately rest on an individual's right to exclude others froin his land, possessions, or person.

\section{B. Property Rights as a Basis for Fourth Amendment Rights}

Over the last twenty-five years, the Supreme Court has consistently used property concepts to examine privacy expectations. Katz sought to escape property-based criteria in determining Fourth Amendunent rights. But in applying Katz's reasonableness test, courts must fall back on objective criteria. Any assessment of the expectation of a defendant will ultimately rest upon whether he had a property interest in the objectwhether he abandoned it, whether he was trespassing on another's land, etc. Katz's focus on the defendant's expectation rather than on the area searched seened logical, but the same criteria that were used to assess whether or not the searched area was constitutionally protected are now used to "fill in" the reasonableness of the privacy expectation.

Prior to Katz, an individual had to show how the police "invaded" a constitutionally protected area. The focus was on the requisite property interest of the defendant and on the law of trespass witli regard to the police conduct. This approach was unsound; the correct approacli, adopted by the Katz Court, focused on the expectation of the defendant. Katz should not be read to abandon all property inquiries, lowever-the reasonableness of the expectation of privacy will depend on these factors. Instead, Katz unust be construed narrowly if it is to be reconciled with subsequent Supreine Court's decisions. Katz inerely shifted the focus of the Fourth Amendment from the search to the searched. In adopting the "reasonable expectation of privacy" standard, the Court acknowledged the importance of the defendant's rights, not the police's actions. Yet the protection afforded by certain areas still exists today. Instead of labelling such areas "constitutionally protected," courts refer to them as "especially conducive" to a reasonable expectation of privacy. The criteria are the same, only the underlying philosophical approacli has changed.

75. David Schmidtz, The Limis of Government: An Essay on the Public Goods ARGUMENT 1 (1991).

76. See, e.g. , Aristotle, The Politics bk. II, ch. 5, in THE BASIC WORKS OF ARISTOTLE 1150-54 (Richard McKeon ed. \& Benjamin Jowett trans., 1941). 
Since Katz, courts have relied on these underlying property principles to examine the interest of the defendant contesting the warrantless search. The defendant's legitimate privacy interest will coincide with a positive entitlement related to soine property right. Soine property interest must be a precondition to a Fourth Amendinent interest. If a person cannot claim any property interest in an object or place, it is unlikely that his expectation of privacy will be reasonable. Of course, property interests of less than full title will often suffice--an invitee to a hoine, ${ }^{77}$ a licensee to an object or place, ${ }^{78}$ or a bailee to a belonging ${ }^{79}$ will all have a legitimate expectation of privacy in their areas or belongings.

The Court has consistently denied that it uses property rights to assess Fourth Amendment interests. ${ }^{80}$ However, in assessing the reasonable expectation of an individual contesting a warrantless search, courts must look to positive law, including property rights, to determine the individual's requisite privacy interest. In the last twenty-five years, the Supreme Court has merely paid lip service to Katz's abhorrence of property-based Fourth Amendment analyses. The Court has regularly used pre-Katz property criteria to determine the interest of the defendant. ${ }^{81}$ An individual who possesses no interest in land cannot expect that the land will not be searched. Likewise, an individual with no property interest in an item cannot expect privacy in that itein. ${ }^{82}$

77. See, e.g., Holloway v. Wolf, 482 F.2d 110 (8th Cir. 1973) (holding that defendant lias standing to object to search of house of third person because defendant was lawfully in house at the time of the search).

78. See, e.g., Katz v. United States, 389 U.S. 347, 352 (1967); infra note 183.

79. See, e.g., United States v. Most, 876 F.2d 191 (D.C. Cir. 1989); infra note 142.

80. See, e.g., Rakas v. Illinois, 439 U.S. 128, 143 (1978) ("[A]rcane distinctions developed in property and tort law between guests, licensees, invitees, and the like, ought not to control.").

81. See California v. Acevedo, 111 S. Ct. 1982, 1991 (1991) (holding that location of closed container in automobile is relevant to the reasonableness of privacy expectation); California v. Greenwood, 486 U.S. 35, 40 (1988) (focusing on area in which abandoned trash bags were located); Oliver v. United States, 466 U.S. 170, 190 (1984) (Marshall, J., dissenting) (using local trespass law to justify expectation of privacy); Rawlings v. Kentucky, 448 U.S. 98, 105 (1980) (discussing "bailment" of drugs to third party in assessing Fourth Amendment rights); Rakas, 439 U.S. at 144 n.12 ("[T] he Court lias not altogether abandoned use of property concepts in determining the presence or absence of the privacy interests protected by that Amendment."); id. at 153 (Powell, J., concurring) ("[P]roperty rights ... . should be considered in deternining whether an individual's expectations of privacy are reasonable.").

82. See, e.g., Sumrall v. United States, 382 F.2d 651 (10th Cir. 1967), cert. denied, 389 U.S. 1055 (1968) (defendant did not liave standing to contest search of codefendant's purse even though defendant was present at the time of searcli); State v. Boutot, 325 A.2d 34 (Me. 1974) (defendant did not lave standing to challenge search of ear lie had stolen).

To furtlier explain the difference between interests that the Fourtl Amendment will protect and strict property interests, consider the ease of a lost wallet. The owner of the wallet retains "title" to his belongings-he still owns the wallet and its contents even thouglh it is lost. If someone who knows the true owner slould pick it up and keep it, he has committed larceny. Thus, proprietary interests are very powerful in a property context. The finder has a possessory interest in the wallet, 
A property interest is a necessary condition for Fourth Amendment protection, but is it a sufficient condition? As Justice Rehnquist stated in Rakas, "even a property interest in premises may not be sufficient to establish a legitimate expectation of privacy with respect to particular items located on the premises or activity conducted thereon." 83 The interest necessary to prevent a warrantless search must be more than mere ownership. In Rawlings v. Kentucky, ${ }^{84}$ the Court acknowledged that an individual does not have a legitimate privacy interest just because he owns an item. ${ }^{85}$ If an individual places an item in "plain view," it is not protected by the Fourth Amendment. ${ }^{86}$ For exanple, when an individual leaves his belongings unattended in a public place, he retains a property interest, but relinquislies the protection of the Fourth Amendment. Similarly, when an individual exposes an object to public scrutiny, he loses his expectation of privacy. ${ }^{87}$ Thus the property interest is necessary to Fourth Amendment protection, but not sufficient. This is not surprising, given Katz's requirement that the privacy expectation be both reasonable and legitimate. Katz never abandoned the use of property concepts in assessing Fourth Amendment protection; it merely shifted the focus of the inquiry froin the area of the search to the person being searched.

\section{Building on KaTZ: Open Fields, Closed Containers, ABANDONMENT, AND TRESPASS}

The Supreme Court began realizimg the implications of the Katz test alınost immediately. Using the sparse guidance that Katz provided, the Court began to develop rules of general reasonableness. Open fields, for

yet this is "trumped" by the owner's interest. If a police officer should pick up the wallet and "search" its belongings, however, the owner could not suppress evidence obtained from such a search-the proprietary interest will be useless in that case. The wallet owner did not maintain a reasonable expectation of privacy. Yet if the finder had the wallet on his person when the police searched it (without warrant or exception to the warrant requirement), he could exclude the evidence as a violation of the Fourth Amendment. In a Fourth Amendment context, possessory interests (in chattel) are more powerful than proprietary interests. Of course, an individual also maintains a reasonable expectation of privacy in his home, office, or other private place, but by virtue of the recognized right to exclude others. The Fourth Amendment protects those privacy interests that society recognizes as reasonable. Property interests govern the right to exclude others, and this right determines which privacy interests are reasonable.

83. 439 U.S. at 144 n.12.

84. 448 U.S. 98 (1980).

85. See id. at 106.

86. For a discussion of the plain view doctrine, see Elsie Romero, Fourth Amendment-Requiring Probable Cause for Searches and Seizures Under the Plain View Doctrine, 78 J. CRIM. L. \& Criminology 763 (1988); Seth H. Ruzi, Comment, Reviving Trespass-Based Search Analysis Under the Open View Doctrine: Dow Chemical Co. v. United States, 63 N.Y.U. L. REv. 191 (1988).

87. See, e.g., California v. Greenwood, 486 U.S. 35, 40 (1988). 
example, are generally not protected against governmental intrusion because the land is subject to the scrutiny of any passers-by; therefore, an expectation of privacy in such fields would not be reasonable. ${ }^{88}$ If the object of the search is not the land itself, but an object in possession of the defendant, closed containers are generally protected because the expectation of privacy in the interior of objects is reasonable. ${ }^{89}$ When such belongings are abandoned, however, the closed containers are not generally protected by the Fourth Amendment because people do not reasonably expect privacy in belongings they have discarded or left unattended. 90 Similarly, when an individual trespasses onto another's land, the reasonableness of the expectation of privacy is necessarily diminished. ${ }^{91}$ Trespassers' expectations may still be reasonable in solne situations,, 92 but not when the belongings are left on someone else's land. Understanding how courts deal with these issues is crucial to understanding Mooney.

\section{A. Open Fields}

Because Mooney lived under a public bridge, an open area accessible to passers-by, it is important to understand the way in which "open fields" have been treated in assessing Fourth Amendment rights. In Hester v. United States, ${ }^{93}$ the Supreme Court determined that there was no Fourth Amendment violation when police, trespassing on the defendant's land without a warrant, noticed in an open field several bottles of "moonshine whiskey" dropped by the defendant in flight. ${ }^{94}$ Reasoning that "[t]he distinction between [open fields] and [one's] house is as old as the common law," the Court held that the Fourth Amendment does not extend to open fields.95 Writing for the Court, Justice Holines rejected the defendant's trespass argument: The police's action of trespassing

\footnotetext{
88. See infra Part III(A).

89. See infra Part III(B).

90. See infra Part III(C).

91. See infra Part III(D).
}

92. For example, a "technical trespasser," such as a child crossing a neighbor's yard on the way to school, does not consent to police searches neerely by stepping on sonieone else's land. The distinction is that the technical trespasser has not given up any expectation of privacy in his person or the objects he possesses. See infra note 216 and accompanying text. The trespass cases discussed in Part III(D), infra, deal with the expectation of privacy in objects left on another's land or in the land itself. These are the issues raised by Mooney.

93. 265 U.S. 57 (1924).

94. Id. at 58-59. For a nore thorough discussion of the open fields doctrine, see generally Bradley W. Foster, Warrantless Aerial Surveillance and the Right to Privacy: The Flight of the Fourth Amendment, 56 J. AIR L. \& Сом. 719 (1991).

95. 265 U.S. at 59. 
onto the defendant's land without a warrant did not amount to a search because the defendant's own acts exposed the bottles to plain view. ${ }^{96}$

The "open fields" doctrine created in Hester survived the Katz reforinulation; an expectation of privacy in an open field is generally unreasonable because any passers-by can readily view the object of the search. In Oliver $v$. United States, ${ }^{97}$ the Court expanded this doctrine. The police had entered the defendant's field, which was partially enclosed by a locked gate displaying a "No Trespassing" sign, and found a inarijuana crop. ${ }^{98}$ The trial court found a reasonable expectation of privacy because the defendant "[had done] all that could be expected of him to assert his privacy in the area of farm that was searched."99 Furthermore, the farm was located in a secluded area not easily seen by the public. Thus the trial court concluded that the farm was not an "open" field and, therefore, that it deserved Fourth Amendment protection. ${ }^{100}$ The Supreine Court reasoned, however, that "an individual inay not legitimately demand privacy for activities conducted out of doors in fields, except in the area immediately surrounding the home."101 Because Katz protects "people, not places,"102 the issue turns on what expectation of privacy society will accept:

[O]pen fields do not provide the setting for those intimate activities that the Amendment is intended to shelter from government interference or surveillance. There is no societal interest in protecting the privacy of those activities, such as the cultivation of crops, that occur im open fields. Moreover, as a practical matter these lands usually are accessible to the public and policc in ways that a home, an office, or commercial structure would not be. ${ }^{103}$

96. Id. at 58. As will be shown in Part III(C), infra, the defendant's "abandonment" of the searched item prior to the warrantless search often defeats any potential Fourth Amendment claim. See California v. Greenwood, 486 U.S. 35 (1988) (abandoned trash bags held to be unprotected by the Fourth Amendment); United States v. Thomas, 864 F.2d 843 (D.C. Cir. 1989) (abandoned gym bag held to be unprotected). The issue of abandonment is crucial to Mooney. See infra notes 200-07 and aecompanying text.

97. 466 U.S. 170 (1984).

98. Id. at 173.

99. Id. (quoting App. to Pet. for Cert. at 23-24, Oliver (No. 85-15)).

100. Id. at 174. The court of appeals reversed, but four dissenting judges argued that the open fields doctrine did not apply where reasonable efforts were made to exclude the public. United States v. Oliver, 686 F.2d 356, 372 (6th Cir. 1982) (en banc). One judge argued that the open fields doctrine applied only when the land could actually be viewed by the public. Id. at 373; see Oliver, 466 U.S. at 174 n.3.

101. 466 U.S. at 178.

102. Katz v. United States, 389 U.S. 347, 351 (1967).

103. Oliver, 466 U.S. at 179 (emphasis added). 
The overriding factor in post-Katz analyses is the reasonableness of the expectation of privacy. In an open field, this expectation cannot be reasonable. The Oliver Court distinguished between the "reasonable" expectation of privacy and the "legitimate"104 expectation of privacy required by Katz. The defendant had inade every effort to conceal his crop; and thus it may have been reasonable to expect privacy in such a reinote and secluded place. However, the police did not violate a societally protected privacy interest. "The test of legitimacy is not whether the individual chooses to conceal assertedly 'private' activity. Rather, the correct inquiry is whether the government's intrusion infringes upon the personal and societal values protected by the Fourth Amendment."105

Justice Marshall's dissenting opimion in Oliver outlined the Court's Fourth Amendment methodology. Although Justice Marshall reached a different conclusion than the majority in Oliver, his approach to analyzing the privacy expectation of defendants asserting Fourth Amendment protection is the one generally used by the Court. In determining whether a defendant's expectation of privacy is reasonable, the Court looks to various factors. Although there are no steadfast rules, Justice Marshall categorized three factors to examine in all Fourth Amendment analyses.

First, we consider whether the expectation at issue is rooted in entitlements defined by positive law. Second, we consider the nature of the uses to which spaces of the sort in question can be put. Third, we consider whether the person claiming a privacy interest inanifested that interest to the public in a way that inost people would understand and respect. 106

In expounding the first principle, the Court looked to property rights as the type of positive law that creates privacy interests. One of the inost important rights associated with ownership is the right to exclude. ${ }^{107}$ As Justice Relınquist stated in Rakas v. Illinois, "one who owns or lawfully

104. In United States v. White, 401 U.S. 745, 752 (1971), the Court used the term "justifiable" to express Katz's requirenient that the expectation of privacy be one that society is prepared to recognize as reasonable. In Oliver the Court used the term "legitinate." See supra note 63.

105. Oliver, 466 U.S. at $\mathbf{1 8 2 - 8 3}$ (footnote omitted).

106. Id. at 189 (Marshall, J., dissenting).

107. See Loretto v. Teleprompter Manhattan CATV Corp., 458 U.S. 419, 435 (1982) ("The power to exclude has traditionally been considered one of the nost treasured strands in an owner's bundle of property rights."); see also Kaiser Aetna v. United States, 444 U.S. 164 (1979) (discussing power to exclude as property strand worthy of compensation under Fifth Amendment takings clause); Restatement OF PROPERTY $§ 7$ (1936). 
possesses or controls property will in all likelihood have a legitinate expectation of privacy by virtue of [the] right to exclude [others]."108 Justice Marshall concluded that Otiver's ownership of his field entitled him to certain positive rights which reflected the reasonableness of his expectation of privacy. ${ }^{109}$ Nevertheless, the majority held that Oliver had exposed his field to the public, overriding any property right to exclude. ${ }^{110}$ Justice Marshall's second factor, the use to which the place is put, arguably weighed in favor of the defendant. Society will recognize some legitimate uses of an open field im which people may expect privacy. The third factor, the steps taken to ensure that the privacy expectation is understood and respected, also weighed in favor of the defendant Oliver. Oliver had taken precautions to maintain his privacy: He had posted "No Trespassing" signs along his property and had partially enclosed the field with a fence. Despite these arguably positive factors, the majority concluded that tlie defendant could not have manifested a reasonable expectation of privacy in his open field because such an expectation was not one society would be willing to accept as reasonable.111

The Court expanded the open fields doctrine in California $v$. Ciraolo. ${ }^{112}$ The Court held that a field exposed to aerial surveillance was "open" and therefore not protected by the Fourth Amendment, although it was sufficiently sheltered from the public at ground level. The defendant had enclosed his marijuana field witl a six-foot outer fence and a tenfoot inner fence. ${ }^{113}$ However, on a tip, police conducted aerial surveillance of the field and noticed large marijuana crops. ${ }^{114}$ The defendant argned that lie had taken normal precautions to maintain his privacy.115 Yet the Court concluded that "[a]ny member of the public flying im this airspace who glanced down could liave seen everything that [the] officers observed. ... [The] expectation that his garden was protected from such observation is unreasonable and is not an expectation that society is prepared to honor." 116 The determinative factor is whetler the public could readily or even possibly observe the object of the "search" that the police

108. 439 U.S. 128, 144 n.12 (1978); see also id. at 153 (Powell, J., concurring) ("[P]roperty rights refiect society's explicit recognition of a person's authority to act as he wishes in certain areas, and therefore should be considered in determining whether an individual's expectations of privacy are reasonable.").

109. Oliver, 466 U.S. at 191 (Marshall, J., dissenting).

110. Id. at 179.

111. Id. at 181 .

112. 476 U.S. 207 (1986).

113. Id. at 209.

114. Id.

115. See Rawlings v. Kentucky, 448 U.S. 98, 105 (1980) (requiring that defendants seeking Fourth Amendment protection take "normal precautions" to ensure privacy).

116. Ciraolo, 476 U.S. at 213-14. 
conducted. If the field is accessible to the public in one way or another, it will not be protected.

With the Oliver and Ciraolo decisions, the open fields doctrine was greatly expanded; open fields are considered exposed to the public if they can be viewed from any legitimate vantage point. That is, if the public can generally observe the field itself, objects in the field, or activities conducted in the field, the field will not receive Fourth Amendınent protection. The Court has delineated certain criteria to determine whether the field is protected. In Oliver, the Court inquired whether the field was "accessible to the public"-this included trespassers who inay wander onto the field. ${ }^{117}$ If it is somewhat likely that the field could be observed, it will not be protected. In Ciraolo, the field was subject to the "knothole in the fence" test: If there is an opening, whether it be a hole in a fence or the sky above the field, the police may look into it. ${ }^{118}$ Thus privately owned fields, even ones shielded from most of the public, are not protected from warrantless searches if it is likely or even possible that the field may be observed.

\section{B. Closed Containers}

Mooney's claims for Fourth Amendinent protection rested to a large degree upon his use of a closed duffel bag and a suitcase to hide his belongings. The Fourth Amendment protects "persons, houses, papers, and effects" against unlawful search and seizure. Traditionally, these items were protected when located in a home. After Katz, the Court expanded the protection to include personal effects that were not on the person but were otherwise private.

In United States v. Chadwick, 119 the Court held reasonable the expectation of privacy in the interior of a footlocker loaded onto a vehicle. ${ }^{120}$ Although the locker was not in a traditionally protected area, the

117. 466 U.S. at 179 .

118. The State of California used the "knothole" analogy in its Petition for Certiorari. See Ciraolo, 476 U.S. at 210. I have used the analogy as an open fields "test." Other courts have concluded that fields meeting these criteria are not worthy of Fourth Amendment protection. See, e.g., United States v. Rucinski, 658 F.2d 741 (10th Cir. 1981) (holding no Fourth Amendment protection against invasion of field where millyard surrounded by nothing more than barbed wire fence).

119. 433 U.S. 1 (1977).

120. Id. at 11. Although the "automobile exception" requirements of Chadwick have been recently overruled by California v. Acevedo, 111 S. Ct. 1982 (1991), the heightened protection given to closed containers still exists. This protection developed from a series of cases dealing with searclies of closed containers found in automobiles. The police conducted a search of Mooney's closed containers under a bridge abutment and not in an automobile; therefore, a discussion of the "automobile exception" is not within the scope of this Note. For a discussion of the closed container doctrinc with regard to automobile searches, sec id.; Catherine A. Shepard, Comment, Search and Seizure: From Carroll to Ross, the Odyssey of the Automobile Exception, 32 CATH. U. L. REV. 221 (1982); see 
expectation of privacy in the interior of the locker was reasonable because society regards locked footlockers as iteins in which people expect privacy. ${ }^{121}$ The Court argued that because society has traditionally given great deference to the privacy of belongings placed in closed containers such as luggage, it is reasonable to expect that a closed container would remain unopened. ${ }^{122}$

The Court expanded this "closed containers" doctrine in Robbins $v$. California. ${ }^{123}$ There the Court held that the expectation of privacy was reasonable even in opaque wrappers. The Court expanded the definition of a closed container: "Once placed within a [closed, opaque] container, a diary and a dishpan are equally protected by the Fourth Amendment."124 One who places an object inside any closed container manifests an intent to keep that item private, and society regards this privacy interest as reasonable.

\section{Abandonment}

The protection an individual retains by placing a personal effect inside a closed container is lost when that closed container is abandoned. Abandonment itself does not present a great challenge to search and seizure scholars: One cannot manifest a reasonable expectation of privacy in an item once it has been abandoned. ${ }^{125}$ The problein is in determining when a given item has been abandoned. This question is often difficult to resolve.

In California v. Greenwood, ${ }^{126}$ the Court held that there was no reasonable expectation of privacy in the contents of discarded trash bags left

also United States v. Ross, 456 U.S. 798 (1982); Arkansas v. Sanders, 442 U.S. 753 (1979); Carroll v. United States, 267 U.S. 132 (1925).

121. "By placing personal effects inside a double-locked footlocker, [one] nuanifest[s] an expectation that the contents would remain free from public examination." Chadwick, 433 U.S. at 11.

122. Id.

123. 453 U.S. 420 (1981). As with Chadwick, Robbins has been overruled in part by Acevedo with regard to the automobile exception.

124. Id. at 426. The Court does not distinguish between types of containers: "What one person may put into a suitcase, another may put into a paper bag." Id.

125. E.g., Abel v. United States, 362 U.S. 217, 241 (1960) (holding that discarded papers found in a hotel wastebasket after defendant lad vacated the room were not subjects of Fourth Amendment protection); Hester v. United States, 265 U.S. 57 (1924) (holding that no seizure oceured where itens were dropped during police cliase). Although these cases pre-date Katz, the law created by them is still good: Katz acknowledged the limitations on Fourth Amendment protection when the object searcled las been exposed to public scrutiny. "What a person knowingly exposes to the public, even in his own lome or office, is not a subject of Fourth Amendment protection." Katz, 389 U.S. at 351; see also Edward G. Mascolo, The Role of Abandonment in the Law of Search and Seizure: An Application of Misdirected Emphasis, 20 BuFF. L. REv. 399, 400 (1971) ("[W]here one abandons property, he is said to bring his right of privacy therein to an end ... and the property so abandoned nay be seized without probable cause.").

126. 486 U.S. 35 (1988). 
out for collection. ${ }^{127}$ Although the closed garbage bags were opaque containers, once the owner discarded them outside the curtilage, the expectation of privacy ceased to be reasonable. Because the area was "readily accessible to animals, children, scavengers, snoops, and other members of the public," the expectation that the bags would remain private was unreasonable. ${ }^{128}$

The decision in Greenwood marked a retreat from previous closed container decisions. Under prior cases, the expectation of privacy in items placed im closed containers was generally assumed to be reasonable because society regards any container like luggage to be inherently private. ${ }^{129}$ But the Katz test required a determination of surrounding factors to ascertain the reasonableness of the defendant's expectation of privacy; deeming certain objects inherently private seemed too mucli like the old "constitutionally protected area" standard. Chadwick lield that the expectation of privacy was reasonable in a double-locked footlocker; Greenwood determined that such protection of closed containers does not extend to trash bags that liave been abandoned and are accessible to the public. Under Katz, the only question for a court is whether society is willing to accept as reasonable an expectation of privacy in the searched object. Even the most closed and secret possession inay be searched witliout warrant if society thinks that the expectation of privacy was defeated by surrounding circumstances such as abandonment.

Greenwood represents another example of the reasonable/legitimate expectations dichotomy. ${ }^{130}$ Greenwood almost certainly believed that his trasli bags left on the curb would remam free from inspection (thius satisfying the subjective coinponent). In fact, this behef was probably reasonable given the slim chance of the pohce searching his trash. However, the pohice officer's discovery of the evidence did not violate Greenwood's Fourth Amendment riglits because the expectation of privacy was not one society is willing to accept as reasonable. Because the garbage collector himself could have sorted through the garbage or allowed someone else to do so, society could not view such an expectation of privacy as reasonable. ${ }^{131}$ The fact that there was little cliance of someone actually discovering the narcotics does not increase the legitinacy of the expectation. Greenwood abandoned his reasonable expectation of privacy in the trash bags and could not legitimately expect them to remain free from imspection.

\footnotetext{
127. Id. at 40 .

128. Id.

129. See United States v. Chadwick, 433 U.S. 1, 11 (1977).

130. See supra notes $62-66$ and accompanying text.

131. Greenwood, 486 U.S. at 40.
} 
In United States v. Thomas, ${ }^{132}$ the United States Court of Appeals for the D.C. Circuit, applying Greenwood, set out a test for ascertaining when an iten has been abandoned by a defendant. In Thomas, the defendant, upon seeing the police approaching the courtyard of his apartinent, had dropped his gyn bag on the second floor landing and exited the building. The police entered the building, found the bag, and searclied it, discovering various firearms, ammunition, and cocaine. ${ }^{133}$ The court lield that the expectation of privacy in the contents of the dropped and abandoned gym bag was not reasonable, although the defendant liad intended to return to retrieve the bag. ${ }^{134}$ Thomas summarized the abandonment inetlodology:

The test for abandonment in the search and seizure context is distinct from the property law notion of abandonment: it is possible for a person to retain a property interest in an item, but nonetheless to relinquish his or her reasonable expectation of privacy in the object. To determine whether there is abandonment in the fourth amendment sense, the district court must focus on the intent of the person who is alleged to have abandoned the ... object. The test is an objective one, and intent may be inferred from "words spoken, acts done, and other objective facts." 135

The defendant's conduct-dropping his bag and fleeing-indicated (objectively) an intent to abandon his possessions, and he therefore lost his reasonable expectation of privacy. The fact that the defendant actually (subjectively) intended to retain ownership is irrelevant.

Other courts liave rehed on the Thomas approacl to assessing abandonment. It is apparent that abandonment can be effectuated by denouncing ownership ${ }^{136}$ or by actively discarding the itern. ${ }^{137}$ Thomas

132. 864 F.2d 843 (D.C. Cir. 1989).

133. Id. at 845 .

134. Id. The court concluded that the defendant's intention to retrieve the bag had no bearing on his reasonable expectation of privacy. "The legal significance of Thomas' acts is not altered by the fact that he might have intended to retrieve the bag later. His ability to do so would depend on the fortuity that other persons with access to the public hallway would not disturb his bag while it lay there unattended." Id. at 846 n.5; see United States v. Jones, 707 F.2d 1169, 1172 (10th Cir. 1983) ("[The defendant's] ability to recover the satchel depended entirely upon fate and the absence of inquisitive (and acquisitive) passers-by.").

135. Thomas, 864 F.2d at 845-46 (citations and footnote omitted).

136. See, e.g., United States v. Lee, 916 F.2d 814 (2d Cir. 1990) (defendant who adamantly denied ownership of luggage checked at airline did not have recourse under Fourth Amendinent); United States v. Carrasquillo, 877 F.2d 73, 76 (D.C. Cir. 1989) ("Because the defendant denied ownership ... the bag was legally 'abandoned' and the agents were free to search it without a warrant."); United States v. Brady, 842 F.2d 1313, 1316 (D.C. Cir. 1988) ("[S]pontaneous denial of ownership, unaffected by police provocation, dernonstrates sufficient intent of disassociation to prove abandoninent."). Compare Uirited States v. Sanders, 719 F.2d 882 (6th Cir. 1983) (defendant who, believing she was under surveillance, left airport without retrieving checked suitcase, but did not deny ownership of suitcase when questioned by police, did not relinquish reasonable expectation of privacy) with United States v. Tolbert, 692 F.2d 1041 (6th Cir. 1982) (defendant who left airport 
does not suggest that a person must "assertively clutch" an object at all times to retain the protection of the Fourth Amendment. ${ }^{138}$ Rather, the court looks for actions that indicate an intent to relinquish the privacy interest. One such action is leaving the itein in a public place. For exainple, in City of St. Paul v. Vaughn, ${ }^{139}$ the owner of an eyeglass case containing drug paraphernalia relinquished his reasonable expectation of privacy when he hid the case in a public dry cleaning estabhishment. The court held that when "the discard occurs in a public place where the defendant cannot reasonably have any continued expectancy of privacy in the discarded property, the property will be deemed abandoned for the purposes of search and seizure."140

Another factor that can affect abandonment is how long the defendant leaves the object open to public scrutiny. ${ }^{141}$ The coinmon theme in airline clecked luggage cases is that when a person entrusts an airline employee or similar person to hold an object, the reasonable expectation of privacy is not relinquislied. ${ }^{142}$ However, the expectation of privacy ceases to be reasonable when the person denies ownership or takes actions indicating an intent to abandon the object, sucl as leaving it in public for an unreasonable amount of time.

without retrieving checked luggage and denied having any luggage when questioned by police had abandoned suitcase for Fourth Amendment purposes). But see State v. Huether, 453 N.W.2d 778, 781 (N.D. 1990) ("[D]isavowal of ownership alone may not be enough to relinquish one's reasonable expectation of privacy.").

137. See, e.g., United States v. Collins, 766 F.2d 219 (6th Cir.) (per curiam) (drug defendant renounced reasonable expectation of privacy when he discarded bag during police chase), cert. denied, 474 U.S. 851 (1985); People v. Mamon, 457 N.W.2d 623 (Mich. 1990) (same); see also Hester v. United States, 265 U.S. 57 (1924). Items abandoned during a police chase are not protected by the Fourth Amendment if the police had probable cause to initiate the chase. Thomas, 864 F.2d at 846 n.4. In Thomas, the bag was abandoned before the police confronted the defendant. Thus, the court did not accept Thomas's argument that the pohice induced his abandonment. Id. "[O]nce the bag was abandoned, the officers did not require probable cause to search it." Id. at 847.

138. Thomas, 864 F.2d at 846 .

139. 237 N.W.2d 365 (Minn. 1975).

140. Id. at 371 (footnotes omitted).

141. See, e.g., United States v. Oswald, 783 F.2d 663 (6th Cir. 1986) (defendant who left suitcase for only twenty-four hours in trunk of automobile that had caught fire had abandoned suitcase for Fourth Amendment purposes); cf. United States v. Jackson, 544 F.2d 407 (9th Cir. 1976) (defendant's actions of dropping suitcase and taking thrce steps away from it before arrest not sufficient to constitute abandonment under Fourth Amendment); State v. Beresford, 592 A.2d 882 (Vt. 1991) (defendant who made no attempt to leave scene of aceident had not abandoned shaving kit found twenty-five feet from overturned truck).

142. Likewise, in United States v. Most, 876 F.2d 191 (D.C. Cir. 1989), the court held that a defendant who had deposited a plastic bag with a grocery store employee had not relinquished his reasonable expectation of privacy. "Most ... did not place his bag within the reach of the world generally." Id. at 197. 


\section{Trespass ${ }^{143}$}

Although Katz expanded Fourth Amendment protection to include areas other than just the strict confines of a home or office, ${ }^{144}$ this protection does not extend to places where the defendant has no property interest. Just as a defendant who leaves his suitcase in Grand Central Station for two weeks has abandoned his reasonable expectation of privacy, a stowaway on a cruise ship cannot complain of warrantless invasion when his unattended belongings are searched. The question of trespass has been difficult to resolve; at some point a trespasser has shared his space with so many others that any expectation of privacy must be unreasonable. ${ }^{145}$

The Supreme Court's original test for Fourth Amendment standing required that the defendant be "legitimately on the prenrises." 146 Thus a defendant could not even challenge a search unless he was legitimately on the premises searched. In Rakas v. Illinois, however, the Court abandoned the "legitimately on the premises" test. ${ }^{147}$ Rakas dealt with the privacy expectation of passengers in a getaway car driven by the owner. Although the defendants were "legitimately on the preinises" in the sense that they had the owner's permission to be in the car, the Court concluded that they could not have had a rcasonable expectation of privacy in the glove compartinent and in the area nnder the carseats: "Like the trunk of an automobile, these are areas in which a passenger qua passenger sinply would not normally have a legitimate expectation of privacy." 148

In any Fourth Amendment inquiry, a court must examine all the surrounding circumstances. ${ }^{149}$ And, because property rights will often bear on the rcasonableness of the privacy expectation, ${ }^{150}$ trespassers will not usually have reasonable expectations of privacy. ${ }^{151}$ Courts have generally agreed that trespassers lose much of the protection of the Fourth

143. Cases analyzed in this Section do not necessarily involve trespass in the strict sense of the word. Rather, this Note analyzes cases in which individuals do not have a proprietary interest in the area searched.

144. "[A] person can have a legally sufficient interest in a place other than his own home so that the Fourth Amendment protects him froin unreasonable governmental intrusion into that place." Rakas v. Illinois, 439 U.S. 128, 142 (1978).

145. See id. at 146.

146. Jones v. United States, 362 U.S. 257, 267 (1960).

147. 439 U.S. at 143.

148. Id. at 148-49.

149. Id. at 152 (Powell, J., concurring).

150. See supra Part II(B).

151. It is important to note that the trespasser retains the protection of the Fourth Amendment with regard to his person. A person does not lose all protection by stepping onto another's property. The trespasser cases discussed in this Section usually deal with a semi-permanent trespass in which 
Amendment with regard to their "homes." The Tenth Circuit held in United States v. Ruckman ${ }^{152}$ that a trespasser in a cave located on public land could not have had a reasonable expectation of privacy ${ }^{153}$ although he had hived in the cave for eight inonths, had built a door on the cave, and had even fashioned a crude bed. ${ }^{154}$ Because the area was accessible to animals and other people, it was unreasonable to expect privacy. Furthermore, the defendant could have been expelled from the land at any time. ${ }^{155}$ Thus the court determined that the warrantless search did not violate the Fourth Amendment. Likewise, the First Circuit held in Amezquita v. Hernandez-Colon ${ }^{156}$ that squatters on public land had no legitimate expectation of privacy. ${ }^{157}$

In G. R. v. State, ${ }^{158}$ a trespasser in a log cabin was found not to have had a reasonable expectation of privacy in the surroundimg area. ${ }^{159}$ The case did not decide the more interesting question of whether the defendant could have had a reasonable expectation of privacy in the interior of the cabim in which he frequently trespassed. A determination of this question would depend on how accessible the cabin was to the public at

the searched area is the trespasser's "home." Because a court must assess the reasonableness of the expectation of privacy based on of all the surrounding circunstances, a technical trespasser will be protected against unreasonable searches when his conduct indicates an intention to keep his belongings private. This would certainly apply to an individual who steps onto another's property. The important question for cases like Mooney is whether a person who lives on public land can reasonably expect privacy in his home and his belongings.

152. 806 F.2d 1471 (10th Cir. 1986).

153. Id.

154. Id. at 1478 (McKay, J., dissenting).

155. Id. at 1473 .

156. 518 F.2d 8 (1st Cir. 1975).

157. "The plaintiffs knew they had no colorable claim to occupy the land ... . That fact alone makes ludicrous any claim that they had a reasonable expectation of privacy." Id. at 11; see also People v. Smith, 448 N.Y.S.2d 404 (Sup. Ct. 1982) (ordering hearing on Fourth Amendinent rights of subtenant of a squatter); People v. Sumlin, 431 N.Y.S.2d 967 (Sup. Ct. 1980) (casual guest of employee of squatter in city-owned abandoned building did not have reasonable expectation of privacy). Amezquita rehed on cases involving similar fact situations. For cases involving expired rental periods, see Umited States v. Parizo, 514 F.2d 52, 54 (2d Cir. 1975) ("[W] hen the term of a guest's occupancy of a room expires, the guest loses his exclusive right to privacy in the room."); United States v. Croft, 429 F.2d 884, 887 (10th Cir. 1970) ("When the rental period has elapsed, the guest has completely lost his right to use the room and any privacy associated with it."); State v. Roff, 424 P.2d 643 (Wash. 1967) (holding police search of hotel room twenty-four hours after expiration of rental period not violative of Fourth Amendment). Of course, with an expired hotel rental period, the guest knows that the room will be entered because the presurnption is that the guest will not renew. Thus his expectation of privacy after that time is clearly unreasonable. The situation is different for apartment and house rentals, where the renter inay renew for another period. E.g., United States v. Botelho, 360 F. Supp. 620 (D. Haw. 1973) (holding that nonpayment of rent, electricity, and telephone bills does not make defendant's expectation of privacy in cottage unreasonable even though defendant was notified orally of pending eviction).

158. 638 P.2d 191 (Alaska Ct. App. 1981).

159. Id. at 196. 
large. If the defendant could not expect his belongings to remain free from invasion from other people, then he should not expect privacy from the police. "Even if [they] believed the land to be private property, they were aware it was not theirs .... [T] hey had hittle reason to beheve that others would not trespass as they had."160

The underlying rationale in trespasser cases is that a lack of property rights diminishes the reasonableness of a privacy expectation. A trespasser cannot fall back on positive property entitlements (which may include the right to exclude others). ${ }^{161}$ Furthermore, the area is shared with so many others that the defendant cannot reasonably expect that the area will remain free from inspection by others. Of course, "the [Fourth] Amendment does not shield only those who have title to the searched premises."162 Nevertheless, lack of property rights in an area will diminish the reasonableness of the expectation of privacy in that area. It is important, however, to distinginish between searches of an area (which may reveal exposed items) and searches of the person. If an individual possesses items on his person, the fact that he trespasses onto another's land will have little effect upon his expectation of privacy. ${ }^{163}$ However, when a person leaves belongings unattended on another's property or on public property, the expectation of privacy is diminislied. ${ }^{164}$ Similarly, when an individual without a proprietary interest in the land subjected to a police searcli seeks Fourth Amendment protection in that area, his lack of property rights will surely defeat his reasonable expectation of privacy in that area. ${ }^{165} \mathrm{He}$ may, however, exclude others from belongings he physically possesses at the time of the search-those items will be protected by the Fourth Amendment.

160. Id. at 197.

161. The Amezquita court likened the squatters' Fourth Amendment rights to those of car thieves. See Amezquita, 518 F.2d at 11; State v. Boutot, 325 A.2d 34 (Me. 1974) (holding that defendant had no reasonable expectation of privacy in car he had stolen); see also Meade v. Cox, 310 F. Supp. 233, 238 (W.D. Va.) ("No one can expect or demand privacy in premises or places which are wrongfully possessed or in which no interest or ownership can be shown ...."), affd on another ground, 438 F.2d 323 (4th Cir. 1970); State v. Pokini, 367 P.2d 499, 509 (Haw. 1961) ("[A] trespasser who places his property where it has no right to be has no right of privacy as to that property.").

162. Mancusi v. DeForte, 392 U.S. 364, 367 (1968).

163. "An individual who enters a place defined to be 'public' for Fourth Amendment analysis does not lose all claims to privacy .... [T] he Fourth Amendment's protection] against ... unreasonable seizure of effects upon the person remain[s] fully applicable." Oliver v. United States, 466 U.S. 170,179 n.10 (1984).

164. See United States v. Oswald, 783 F.2d 663, 666-67 (6th Cir. 1986) ("[P]rivacy expectations ... vary with the location of the property.").

165. See Rakas v. Illinois, 439 U.S. 128 (1978); United States v. Ruckman, 806 F.2d 1471 (10th Cir. 1986); Amezquita v. Hernandez-Colon, 518 F.2d 8 (1st Cir. 1975). 
IV. CONSTRUCting Homes For the Homeless: STATE v. MOONEY

The Supreme Court of Connecticut struggled with the post-Katz caselaw. The court recognized a "tension" between the protection traditionally given to closed containers and the lack of protection given to property left in open fields and public areas. ${ }^{166}$ Although the court acknowledged that the abandonment cases tended to weigh in favor of the state, ${ }^{167}$ it did not find the caselaw controlling because no abandonment case dealt with the specific circnmstances of Mooney's case. Instead, the majority created "first principles"168 to decide the outcome. Because the closed containers represented Mooney's "last shred of privacy," and because holding otherwise would force Mooney to forgo Fourth Amendment protection for all belongings not physically possessed at the time of the search, the court held that Mooney had had a reasonable expectation of privacy in the closed containers. ${ }^{169}$ Nevertheless, it is important to understand why Mooney's claim to a reasonable expectation in his "home" must fail im order to understand why his closed container claim must fail as well. ${ }^{170}$

\section{A. Invasion of the "Home"}

It is apparent that the Fourth Amendment was originally created to protect people from invasion of their homes. This inost sacred protection is and has been the heart of search and seizure law: "The poorest man may, in his cottage, bid defiance to all the force of the Crown."171 How. ever, this protection must be within reason. A person may not lay down in the middle of the local bus depot and declare, "From here on out, this space is my home. Nobody touch my stuff-I expect some privacy." Mooney's home was neither cottage nor bus depot, but was rather something in between.

The Supreme Court of Connecticut never addressed Mooney's first claim concerning his "hoine," as it found merit in Mooney's closed container clainn. ${ }^{172}$ To assess the privacy interest Mooney claimed in his

166. State v. Mooney, 588 A.2d at 155 (Conn.), cert. denied, 112 S. Ct. 330 (1991).

167. Id. at 159.

168. Id. at 160 .

169. Id. at 161 .

170. The two claims are closely linked. See id. at 172 (Callahan, J., dissenting) ("My conclusion that the defendant liad no legitimate expectation of privacy in the area under the abutment leads me to conclude that he also could not lave reasonably expected that the contents of his containers would remain inviolate if left there unattended.").

171. LAsson, supra note 28, at 49 (quoting William Pitt's famous speecl on general warrants).

172. Mooney, 588 A.2d at 152. 
"home," we must look to whether Mooney could reasonably have expected privacy in the area in which he hived. We can turn to the framework Justice Marshall suggested im Oliver v. United States. ${ }^{173}$ First, we look to positive law for entitlements that could support a claim of privacy. Second, we examine the use to which the land is put. If the land is used in such a way that is recognized as requiring privacy, it will lend credence to Mooney's theory. Third, we look to whether the defendant took normal precautions to put others on notice that he expected privacy.

Mooney hived for four weeks under a bridge abutment under a highway overpass. The abutment was separated from the road by a steep embankment covered by crushed stone and heavy underbrush. The land was owned by the Connecticut Department of Transportation. Because Mooney had no property interest in the land, he could not exclude others; this alone made his expectation of privacy in the area under the bridge unreasonable. Furthermore, the area can be considered an open field in which no reasonable expectation of privacy could inhere. ${ }^{174}$

The area under the bridge abutment was public land. A distinction must be drawn, however, between the type of public land where the public is generally invited, such as a park, and a bridge abutment owned by the state, where people are not generally invited. Such a distinction actually enhances Mooney's argument as fewer people would probably enter such an area. But the effect of such a distinction is that Mooney could be a trespasser on the public land. The extent to which public land can be used can surely be regulated.175 People are not allowed to he in public parks. They certainly are not permitted to live under bridges although they may be technically "public land." Thus Mooney could not reasonably expect that this area would reinain free from inspection or that he would not be ousted. In fact, Mooney acknowledged that a higliway worker had confronted him once during the four weeks in which he lived under the bridge. ${ }^{176}$ Given this confrontation, Mooney could not have reasonably expected that the land would reinam private.

A fact situation similar to that in Mooney occurred in United States v. Ruckman, wliere a trespasser in a pubhic cave was found not to have had a reasonable expectation of privacy. 177 In $R$ uckman, the police entered a cave that the defendant considered his home. The defendant

173. 466 U.S. 170, 189 (1984) (Marshall, J., dissenting); supra text accompanying note 106.

174. See supra Part III(A).

175. See Clark v. Community for Creative Non-Violence, 468 U.S. 288 (1984) (upholding constitutionality of regulation limiting "camping" in United States parks to designated areas).

176. Mooney, 588 A.2d at 151.

177. 806 F.2d 1471 (10tl Cir. 1986). 
could not have had a reasonable expectation of privacy, as he had no right to exclude others from the cave. Furthermore, he could have been ousted at any time.

Even where a defendant makes an attempt to create positive rights, the expectation of privacy is not necessarily reasonable. In Amezquita $v$. Hernandez-Colon, squatters built houses on land that they knew was not theirs. ${ }^{178}$ Ruckman built a door and walls in his cave. ${ }^{179}$ Yet in both of these cases, the courts found that others had just as much right to enter the premises as the defendants, and thus concluded that searches of the defendants' living areas were not violative of the Fourth Amendment. ${ }^{180}$ Mooney knew that others could trespass as he had done. He had encountered a highway worker once before. Moreover, Mooney had moved froin his previous location because another homeless person had started camping nearby. ${ }^{181} \mathrm{He}$ lacked any positive entitlement to the land on which he lived.

Even if Mooney owned the bridge abutinent, the searcli of the area would yet have been permissible under the open field doctrine. Because "an individual may not legitimately demand privacy for activities conducted out of doors in fields, except in the area immediately surrounding the home," 182 a warrantless search of the open area under the bridge would have been permissible. The land was most certainly accessible to the public. Thus under Oliver and Ciraolo, the search would have been legitimate as an open field search.

Justice Marshall's second imquiry in assessing the expectation of privacy in an area examines the use to which the land is put. Some public areas are especially conducive to privacy. For example, in $\mathrm{Katz}$, the defendant entered a telephone booth and closed the door behind hin. Telephone booths are the types of places in which people expect privacy notwithstanding the fact that they are open to the public. ${ }^{183}$ Although

178. "The plaintiffs knew they had no colorable claim to occupy the land .... That fact alone makes ludicrous any claim that they had a reasonable expectation of privacy." 518 F.2d 8, 11 (1st Cir. 1975).

179. Ruckman, 806 F.2d at 1472.

180. "[W] not be decided without any attention to its location or the means by which it was acquired; that is, whether the occupancy and construction were in bad faith is highly relevant." Amezquita, 518 F.2d at 12 .

181. Mooney, 588 A.2d at 151.

182. Oliver v. United States, 466 U.S. 170, 178 (1984).

183. Katz did have a property interest in the telephone bootl-he was a licensee of the space. His Fourth Amendment protection could easily be based on positive property rights, even usufructuary ones, because lie had the right to exclude others from the telephone booth while he was using it. After lie deposited his dime, he possessed certain discernible positive entitlements. See Katz v. United States, 389 U.S. 347, 352 (1967). 
Mooney sought to preserve the bridge abutment as his home, such an area does not share this quality because it is not enclosed and it is not recognized by society as a private place.

The third factor in determining the reasonableness of the expectation of privacy in a given space is "[w] hether a person "took normal precautions to inaintain his privacy." "184 A court must ask whether steps were taken to ensure privacy, and if so, whether these steps have been understood and respected by the public. Mooney had taken considerable steps to ensure his privacy. His belongings included "a blanket used as a mattress, a rolled-up sleeping bag, a closed cardboard box, a suitcase, a small closed duffel bag, and paper trash." 185 He used the cement and metal beains of the highway support structures as shelves and placed all his belongings there, except for the duffel bag, the blanket, and the trash, which were left on the ground. During the one-month period that he lived under the bridge, Mooney was the only occupant. He left the area every day, but secured his belongings so that they could not be seen from the road.

Mooney had done everything that could have been expected of him to ensure his privacy. However, resolution of Justice Marshall's third factor depends on whether the public would understand and respect this privacy. In Oliver, the defendant had owned the land on which the police trespassed, had placed "No Trespassing" signs throughout the area, and had enclosed most of the land with a fence. ${ }^{186}$ Still, the Court found that Ohver could not have reasonably expected privacy because the land was "accessible to the public"-including trespassers who might have wandered onto the land.187 In Ciraolo, the defendant had completely enclosed his land with a ten-foot outer fence and a six-foot inner fence. ${ }^{188}$ The Court found that Ciraolo's land was not protected against police searclies because it was exposed to public scrutiny from passing airplanes. ${ }^{189}$ Altliough botll Oliver and Ciraolo took normal precautions to maintain their privacy, ${ }^{190}$ the public could view eacli of their fields from some vantage point. The Oliver Court concluded that "No Trespassing" signs do not effectively slield an open field from the public. ${ }^{191}$ The

184. Oliver, 466 U.S. at 193 (Marshall, J., dissenting) (quoting Rawlings v. Kentucky, 448 U.S. 98, $105(1980))$.

185. Mooney, 588 A.2d at 150 . All the facts in this discussion are taken from the Connecticut Supreine Court decision.

186. Oliver, 466 U.S. at 173.

187. Id. at 179.

188. California v. Ciraolo, 476 U.S. 207, 209 (1986).

189. Id. at 213-14.

190. See Oliver, 466 U.S. at 173; Ciraolo, 476 U.S. at 211.

191. 466 U.S. at 179. 
Ciraolo Court concluded that an individual who takes ineasures to restrict some points of view does not thereby protect his field from being viewed froin other vantage points where the public has a right to be. ${ }^{192}$ By contrast, Mooney was not on his own property. He did not shield the abutment by a fence. He did not even place "No Trespassing" signs near the bridge. The only measure he took to ensure his privacy was to place his belongings where they could not be seen. This action is insufficient under Oliver and Ciraolo because the items could be viewed from some other vantage point. It is therefore impossible to conclude that Mooney had a reasonable expectation of privacy in the area under the bridge.

A further argument can be inade to show why Mooney could not have had a reasonable expectation of privacy in the area under the bridge. Some courts have argued that the owner of the land can consent to the search of the area where a trespasser or squatter lives. ${ }^{193}$ Because the State of Connecticut owns the land, it can consent to the land being searched. As long as the user of the property has assumed the risk that the owner will consent to a search of the land, he has no recourse if consent is in fact given. ${ }^{194}$ It is unclear whether the Supreme Court would ever adopt such a theory. Nevertheless, under the current expanded open fields doctrine of Oliver and Ciraolo,195 and Rakas and other "trespass" cases, ${ }^{196}$ Mooney's claim that his "hoine" was searched in violation of the Fourth Amendment must fail.

\section{B. Search of the Closed Containers}

Mooney's second claim was that the police violated his Fourth Amendment rights when they searched his closed containers. The Supreme Court of Connecticut agreed with Mooney; the admission of the evidence found under the bridge abutinent was held to be prejudicial error, and the case was remanded for a new trial. ${ }^{197}$ The court reached this

192. 476 U.S. at 213.

193. See, e.g., Government of Virgin Islands v. Gereau, 502 F.2d 914, 926-27 (3d Cir. 1974) ("A trespasser must be deemed to assume the risk that the owner of the property will consent to its search."); see also Amezquita v. Hernandez-Colon, 518 F.2d 8, 12 n.7 (1st Cir. 1975) (describing consent theory).

194. The police consulted the District Attorney's Office prior to the search of the bridge area. The District Attorney determined that no search warrant was needed. Telephone Interview with Judith Rossi, Assistant State's Attorney (Jan. 8, 1992).

195. See supra text accompanying notes 97-118.

196. See supra text accompanying notes 147-65. I refer to Rakas as a "trespass" case only to the extent that it concluded that an individual without a proprietary interest could not have had a reasonable expectation of privacy in an area shared with others.

197. Mooney, 588 A.2d at 161. As indicated earlier, supra note 23, Mooney pleaded no contest to first-degree manslaughter and received a fifteen-year sentence, to be suspended after seven years. He will be eligible for parole in late 1992. 
conclusion by applying illegitimate criteria; under a correct interpretation of the Greenwood standard, Mooney's closed containers should have been deemed abandoned such that the warrantless search of their interiors would not have been violative of the Fourth Amendinent. Open fields cases like Oliver and Ciraolo support this conclusion. Furtherinore, the Thomas court, applying these Supreine Court rulings, concluded that abandonment for Fourth Amendment purposes can result from conduct similar to Mooney's.

After the pohce had arrested Mooney, they found out where he was living and searched the area. Upon arriving at the bridge abutment, a police officer opened Mooney's closed duffel bag and found a large quantity of quarters. He did not open the other items at that time. The belongings were "imventoried" by the police department at a later time. They discovered a size 38 belt ${ }^{198}$ inside the cardboard box. The duffel bag contained about $\$ 700$ in quarters, a pair of bloodstained pants, and some jewelry. ${ }^{199}$

The Mooney court rehed on three factors in holding that the defendant had a reasonable expectation of privacy: the search involved the interior of luggage to which society traditionally affords a great expectation of privacy; the police knew the defendant regarded the area as his home; and the search occurred while the defendant was under arrest for the purpose of obtaining evidence (and thereby "caused" any possible abandonment). These three factors inust be dealt with one at a time. First, although his belongings were closed containers, Mooney abandoned them for Fourth Amendinent purposes. Second, the fact that the police knew Mooney regarded the area as his hoine has no bearing on the reasonable expectation of the defendant. Third, police motive is irrelevant to the question of whether or not the defendant liad a reasonable expectation of privacy. Besides, had Mooney been with his belongings at the time of the search, the search would yet have been valid as a search incident to arrest.

1. Closed Containers. Closed containers are traditionally given great protection under the Fourth Amendment. Society regards items such as suitcases as inherently private. However, when an individual

198. The victim wore a size 38. Mooney did not. Brief for Respondent at 5, Connecticut v. Mooney, 112 S. Ct. 330 (1991) (No. 90-1887). Mooney claimed that he got the belt from a woman who had left it on a park bench. Mooney, 588 A. $2 \mathrm{~d}$ at 151.

199. Mooney, 588 A. 2d at 151. Mooney's accomplice identified the pants as the ones Mooney was wearing on the night of the crime. Brief for Respondent at 5, Mooney, 588 A.2d 145 (No. $13,737)$. 
abandons his belongings, he is said to relinquish his reasonable expectation of privacy. ${ }^{200}$ The question is whether Mooney's actions constituted abandonment.

Abandonment for Fourth Amendment purposes, as we have seen, is different from the property law concept. A person may retain his ownership of an object yet still lose his reasonable expectation of privacy. In Greenwood, the defendant deposited his trash bags on the curb outside his house. This act was sufficient to constitute abandonment because Greenwood "exposed [his] garbage to the public."201 Abandonment in the Fourth Amendment context depends on whether the objects are subject to the scrutimy of the public. Mooney left his closed containers under a bridge. Although he "tucked them away," the closed containers were still exposed to "animals, children, scavengers, snoops, and other members of the public."202 It makes no difference that Greenwood actively discarded the trash bags whereas Mooney intended to retain ownership in his belongings. The test for abandonment is an objective one which depends upon the individual's conduct-" "words spoken, acts done, and other objective [factors].' "203 Mooney's conduct-leaving his belongings unattended under a bridge abutinent-was sufficient to establish abandonment; his intent to retain ownership was irrelevant. Justice Callahan, dissenting in Mooney, reached the same conclusion: "[T]he common theine underlymg the abandonment cases . . . is that it is unlikely that a person can have a reasonable expectation of privacy in a closed container left unattended in a place that is readily accessible to the public."204 Also irrelevant was the fact tliat other people who are likely to come upon Mooney's belongings would be breaking the law by stealing thein. The correct inquiry is whether the closed containers would have been free from inspection, not whether it would have been unlawful to remove or to imspect the containers.

One need not "assertively clutch an object im order to retain the protection of the [F]ourth [A]mendment."205 But the individual who

200. See Katz v. United States, 389 U.S. 347, 351 (1967) ("What a person knowingly exposes to the public . . . is not a subject of Fourth Amendnient protection.").

201. California v. Greenwood, 486 U.S. 35,40 (1988).

202. Id. (citations omitted).

203. United States v. Thomas, 864 F.2d 843, 846 (D.C. Cir. 1989) (quoting United States v. Colbert, 474 F.2d 174, 176 (5th Cir. 1973)); see also City of St. Paul v. Vaughn, 237 N.W.2d 365, 370 (Minn. 1975) ("[Defendant] argues ... that his intention was merely to hide the case, not to relinquish his right of ownership. That is not the test.").

204. Mooney, 588 A.2d at 172 (Callahan, J., dissenting); see also California v. Acevedo, $111 \mathrm{~S}$. Ct. 1982, 1994 (1991) (Scalia, J., concurring) ("[T] he search of a closed container, outside a privately owned building, with probable cause to believe that the container contains contraband ... is not one of those searches whose Fourth Amendnent reasonableness depends upon a warrant.").

205. Thomas, 864 F.2d at 846. 
leaves his closed containers unattended in a place accessible to the public cannot have a reasonable expectation of privacy in the contents for the same reason that lie cannot have a reasonable expectation of privacy in the area as a wliole. Oliver and Ciraolo support this view. Just as Oliver and Ciraolo exposed their fields to public scrutiny, Mooney exposed his objects to public scrutiny. Whetlier or not the public would liave actually inspected his belongings is irrelevant. The distinction drawn between reasonable and legitimate expectations of privacy is crucial liere. Mooney inay liave actually expected privacy. ${ }^{206}$ This expectation inay liave been reasonable-there may liave been little actual cliance of inspection. ${ }^{207}$ Nevertlieless, the law will not prohibit a warrantless search of these abandoned containers, because the expectation of privacy was not legitimate.

2. Police Knowledge of Mooney's "Home." The court considered important the fact that the police knew that Mooney considered the area his "home." The police inotive, in the majority's view, was relevant in assessing the reasonable expectation of privacy tliat tlie defendant exhibited. As the dissenting Justice Callahan noted, lowever, the subjective motives of the police could liave no bearing on whetlier Mooney's expectation of privacy was reasonable. ${ }^{208}$ The fact that the police knew Mooney lived under the bridge abutinent was simply irrelevant to the general inquiry of wlietlier his expectation of privacy was reasonable.

3. Mooney's Arrest "Caused" the Abandonment. The inajority's decision in Mooney rests to some degree on the fact that liad the defendant not been under arrest, his belongings would have been in his possession and not abandoned under Greenwood and Thomas. This argument can be dealt witl in three ways. First, Mooney had abandoned his belongings before lie was arrested. The police could have searched the bridge area first, found the iteins, and tlien arrested Mooney. As lie was not arrested at the bridge abutment, the items were already abandoned. The abandonment was a result of Mooney's actions, not a result of lis arrest. Eacli time he left tlie abutment lie abandoned his reasonable expectation of privacy. Whether or not lie was present at the bridge area at

206. Mooney admitted, however, that he knew the land was state property and that there was "no reason why someone else could not enter or live in the area where he was living." Mooney, 588 A.2d at 151. It is improbable that Mooney knew this and yet expected privacy in the interior of his closed containers. Mooney's two claims are closely linked in this way-his expectation of privacy in the closed containers was probably no greater than his expectation of privacy in the area.

207. This, too, is doubtful. Mooney admitted that a highway worker came upon him during the time he lived under the bridge. Id. Mooney was acutely aware that other homeless people could wander through this area and search his belongings.

208. Id. at 174 (Callahan, J., dissenting). 
the time of the search (allowing him to "reclaim" his belongings) was a matter of pure luck.

Second, the notive of the police in obtaining evidence is irrelevant because it is the reasonableness of the defendant's expectation that is to be assessed, not the conduct of the police. The police motive in arresting Mooney carmot affect this expectation or whether society views it as reasonable.

Third, had Mooney been at the bridge abutment at the time of the search, the search would have becn legitimate as a search incident to a lawful arrest. ${ }^{209}$ Therefore, the majority's rehance on the pohice's role in causing the abandonment was unwarranted. The police had a warrant for Mooney's arrest; they would have found him at the bridge abutment, arrested him, and searched his possessions at that time. Mooney had no reasonable expectation of privacy in his belongings when he left them; and when he was with thein, they could have been searched anyway. Under New York v. Belton, the police can search the contents of any containers found within the passenger compartinent of an automobile after a lawful arrest of the occupant. 210 Thus it seems unlikely that Mooney would have fared any better had he been "at home" the whole time. 211

The Supreme Court of Connecticut applied an erroneous standard to reach the conclusion that Mooney's closed containers were protected by the Fourth Amendment. The court separated the closed containers from the area in which they were located. This approach violates the fundamental assumption of the Chadwick-Sanders rule. ${ }^{212}$ The "automobile exception" developed based on an understanding that the location of the closed container is essential. In assessing the expectation of privacy that a defendant might have, it is critical to consider the surrounding circumstances, such as the location of the objects and their

209. See Chimel v. California, 395 U.S. 752 (1969) (allowing search of arrestee's person and area within immediate control); see also Washington v. Chrisınan, 455 U.S. 1 (1982) (permitting warrantless entry of premises incident to arrest elsewhere); New York v. Belton, 453 U.S. 454 (1981) (holding that warrantless search of pockets of jacket left in autounobile was a search incident to lawful arrest).

210. 453 U.S. at 460.

211. The only case to deal squarely with the intent to retrieve abandoned closed containers is United States v. Thoinas, 864 F.2d 843 (D.C. Cir. 1989). But the court there concluded that the defendant's Fourth Amendment rights were "not altered by the fact that he might have intended to retrieve the bag later." Id. at 846 n.5. "His ability to do so would depend on the fortuity that other persons with access to the public hallway would not disturb his bag while it lay there unattended." Id.

212. United States v. Chadwick, 433 U.S. 1 (1977); Arkansas v. Sanders, 442 U.S. 753 (1979). Although this rule has been overruled recently by California v. Acevedo, 111 S. Ct. 1982 (1991), the location of the searched item is still crucial. See id. at 1991; supra note 120. 
accessibility to the public. The court further erred in placing emphasis upon the fact that Mooney would liave returned to retrieve his belongings. Mooney's intent to return liad no bearing on his expectation of privacy-lie had already abandoned the items at the time of his arrest; or, had he been at the bridge at the time, his belongings would likely have been searclied incident to his lawful arrest. Again, the courts do not draw a distimction between items that are discarded permanently and those tlie owner intends to retrieve. The test is an objective one, determined by the individual's outward conduct, not his intent. Furtlermore, the court mistakenly concluded that the motive of the police im searching the closed containers was relevant. It seems clear that the police motives could not have affected the expectations of the defendant, nor could they liave clianged the defendant's conduct. ${ }^{213}$ The majority's reliance on the fact that the police knew the defendant thouglit the area was his home results in greater protection for a homeless person who leaves his belongings under a bridge abutinent than for a homeowner who places his belongings there. ${ }^{214}$ The Fourth Amendment looks beyond subjective expectations: If the conduct is assessed objectively, the saine conduct cannot provide different results based on the hoineowner status of the individual.

\section{Implications}

The lromeless cannot expect privacy in their belongings left unattended in public places. The implications of this conclusion are minor. A correct application of the Fourtl Amendment to cases such as Mooney does not create a discernible change in what a lomeless individual can reasonably expect.

Consider, for exainple, the trespasser. In Ruckman, the dissent presented an analogy of a cainper on public land wliose visiter pass had expired. ${ }^{215}$ A person may in certain instances liave a reasonable expectation of privacy while trespassing. The fact that the defendant is trespassing is not determinative; the surrounding circumstances need to be assessed to determine whetlier the expectation of privacy was reasonable. A cainper wliose pass lias just expired can safely assume his tent will not be searched, because tlie tent gives him certain rights to exclude. Even if

213. See California v. Ciraolo, 476 U.S. 207, 213 n.2 (1986) (stating that police purpose for conducting search is irrelevant in determining defendants' reasonable expectations).

214. See Mooney, 588 A.2d at 173 (Callahan, J., dissenting) ("Though the intent of the majority in providing heightened fourth amendment protection for the hoineless ... may be adinirable, I find no support ... for the addition of a 'circumstances of the searched' prong to the analysis of whether an expectation of privacy is reasonable.").

215. United States v. Ruckman, 806 F.2d 1471, 1476 (10th Cir. 1986) (McKay, J., dissenting). 
technically trespassing, the camper has certain discernible property rights in the tent. He also has property rights to his person. ${ }^{216}$ That is why a child who crosses a neighbor's property on the way to school does not subject himself to warrantless searches-the trespasser retains his right to exclude others from his person. Trespassing alone does not defeat the imdividual's Fourth Amendment rights because trespassing alone does not defeat the individual's property rights.

Now consider the case of abandonment. A person who leaves his belongings where they are accessible to public scrutiny relinquishes the protection of the Fourth Amendinent, despite his continuing property interest. The reason for this result is that a person loses the ability to exclude others and to exercise dominion over his property when he is not present. Although "title" to the belongings reinains intact-the person has not abandoned the iteins in a property context-the person cannot expect privacy in the objects because he has forsaken certain key property entitlements. For example, the camper could leave his knapsack in his tent on public land without abandoning his expectation of privacy. The tent supphies the necessary property entitlements. But if the camper should leave his knapsack on the ground, in an open public area, he may have abandoned his expectation of privacy. The inquiry is not whether someone would mspect the knapsack or steal it, but whether or not it would be reasonable, im hight of the surrounding circuinstances, to expect that someone would not do so. Suppose a camper leaves his knapsack on a bicycle unattended for a short time in order to use the park restroom. ${ }^{217}$ Would he give up his expectation of privacy? To answer this question requires an assessment of how reasonable it is to leave the iten unprotected. The fact that the knapsack is on a bicycle provides some protection-people are less likely to examine an item left on a bicycle than an item left alone. But the longer the camper leaves his belongings unattended, the more likely it is that they will be inspected-if not by a thief, then at least by a park ranger seeking to identify the owner. If, while the camper is using the restrooin, the park ranger should notice the backpack, examine it to determine the owner, and incidentally discover cocaine, would the camper be able to suppress the evidence? Again, any examination of the expectations of privacy of the individual will depend on the surrounding circuinstances. And these circuinstances will depend on an assessment of his property interest.

216. See John Locke, Two Treatises of Government 328 (Peter Laslett ed., rev. ed. 1960) (1698) ("[E]very Man has a Property in his own Person.").

217. See Mooney, 588 A.2d at 173 n.3 (Callahan, J., dissenting). 


\section{CONCLUSION}

The Mooney decision represents an illegitimate approach to Fourth Amendment law in an uncharted realm. Since Katz, the Supreme Court has consistently looked toward positive property entitleinents im assessing the defendant's privacy interest. Such an approach is necessary to determine what constitutes a "reasonable" expectation of privacy. By acknowledging the importance of such concepts in the search and seizure context, the Court can prevent a double standard in Fourth Amendment jurisprudence. Using property rights as a basis for Fourth Amendment rights, it could much more easily assess the expectation of privacy without diminishing the rights of criminal defendants.

An assumption of this Note has been that the law should apply equally to all members of society. Special protection could be given to homeless people under state constitutions without violating the U.S. Constitution's Fourteenth Amendment guarantee of equal protection; homeowners are not a protected class requiring a strict scrutmy analysis. But a society functions better when everyone receives the same protection of the law. Furthermore, in evaluating the reasonableness of the expectation of privacy, what criteria are to be used? The right to exclude others has been and always will be measured by the yardstick of property. This ultimate truth is at the heart of what the Fourth Amendment protects-the right to be let alone. It is a sad but true fact that those who cannot shut out the world will be subject to its prying eyes. But to create two standards of Fourth Amendment protection in order to rectify the "injustice" of homelessness is to ignore the greater principles encompassed by the Fourth Amendment. 